\title{
The Synergistic Effect of Nitrogen Dopant and Calcination Temperature on the Visible-Light-Induced Photoactivity of N-Doped $\mathrm{TiO}_{2}$
}

\author{
Yao-Tung Lin, ${ }^{1}$ Chih-Huang Weng, ${ }^{2}$ Hui-Jan Hsu, ${ }^{1}$ Yu-Hao Lin, ${ }^{1}$ and Ching-Chang Shiesh ${ }^{3}$ \\ ${ }^{1}$ Department of Soil and Environmental Sciences and Center of Nanoscience and Nanotechnology, \\ National Chung Hsing University, TaiChung 402, Taiwan \\ ${ }^{2}$ Department of Civil and Ecological Engineering, I-Shou University, Kaohsiung 84001, Taiwan \\ ${ }^{3}$ Department of Horticulture, National Chung Hsing University, TaiChung 402, Taiwan
}

Correspondence should be addressed to Yao-Tung Lin; yaotung@nchu.edu.tw

Received 9 January 2013; Revised 28 March 2013; Accepted 29 March 2013

Academic Editor: Jiaguo Yu

Copyright (c) 2013 Yao-Tung Lin et al. This is an open access article distributed under the Creative Commons Attribution License, which permits unrestricted use, distribution, and reproduction in any medium, provided the original work is properly cited.

\begin{abstract}
The synergistic effect of nitrogen content and calcinations temperature on the $\mathrm{N}$-doped $\mathrm{TiO}_{2}$ catalysts prepared by sol-gel method was investigated. The phase and structure, chemical state, optical properties, and surface area/pore distribution of $\mathrm{N}-\mathrm{doped}^{\mathrm{TiO}} \mathrm{F}_{2}$ were characterized using X-ray diffraction spectrometer, high-resolution transmission electron microscope, X-ray photoelectron spectroscopy, UV-vis diffusion reflectance spectroscopy, and Brunauer-Emmett-Teller specific surface area. Finding showed that the photocatalytic activity of $\mathrm{N}$-doped $\mathrm{TiO}_{2}$ was greatly enhanced compared to pure $\mathrm{TiO}_{2}$ under visible irradiation. $\mathrm{N}$ dopants could retard the transformation from anatase to rutile phase. Namely, N-doping effect is attributed to the anatase phase stabilization. The results showed nitrogen atoms were incorporated into the interstitial positions of the $\mathrm{TiO}_{2}$ lattice. Ethylene was used to evaluate the photocatalytic activity of samples under visible-light illumination. The results suggested good anatase crystallization, smaller particle size, and larger surface are beneficial for photocatalytic activity of $\mathrm{N}$-doped $\mathrm{TiO}_{2}$. The $\mathrm{N}$-doped $\mathrm{TiO}_{2}$ catalyst prepared with ammonia to titanium isopropoxide molar ratio of 2.0 and calcinated at $400^{\circ} \mathrm{C}$ showed the best photocatalytic ability.
\end{abstract}

\section{Introduction}

Titanium dioxide $\left(\mathrm{TiO}_{2}\right)$ is an effective photocatalyst due to its inexpensiveness, chemical stability, nontoxicity, biological and chemical inertness, and long-term stability against photo-corrosion and chemical corrosion $[1,2]$. In the last two decades, many works have been done on expanding and augmenting the utility of $\mathrm{TiO}_{2}$ in heterogeneous photocatalysis (e.g., water purification, air cleaning, and water splitting for the production of hydrogen) [2-5], self-cleaning surfaces [6], inactivation of bacteria and fungi $[7,8]$, solar cells [9], anticorrosive coatings [10], and Li-ion batteries [11]. $\mathrm{TiO}_{2}$ has three phases in nature, brookite (orthorhombic), anatase (tetragonal), and rutile (tetragonal). It is amorphous at temperature up to $300^{\circ} \mathrm{C}$, becoming anatase and rutile typically at 350 and $800^{\circ} \mathrm{C}$, respectively [3]. Anatase powder with good crystallinity, small grain size, and high specific surface area is desirable as long as the photocatalytic activity is concerned. However, its wide band gap of 3.2 and $3.0 \mathrm{eV}$ for anatase and rutile polymorphs, respectively, requires UV light for the excitation of electron-hole pairs. It only uses 4$5 \%$ of the UV light in the solar irradiation. To utilize solar energy effectively, many attempts have been made to modify the properties of $\mathrm{TiO}_{2}$, such as doping with transition metal ions [12-14] or nonmetal anions [3, 15-23], and sensitization with organic dyes $[24,25]$. Among the nonmetal-doping $\mathrm{TiO}_{2}$ photocatalysts, the simplest and most feasible $\mathrm{TiO}_{2}$ modification approaches for achieving visible-light-driven photocatalysis seem to be $\mathrm{N}$-doping, that is, doping nitrogen atoms into interstitial (or substitutional) sites in the crystal structure of $\mathrm{TiO}_{2}$. Sato [4] was the first to report on nitrogendoped $\mathrm{TiO}_{2}$. It was treated with various nitrogen sources such as urea, ammonia, ammonium chloride, and nitric acid. Asahi et al. have prepared $\mathrm{TiO}_{2-x} \mathrm{~N}_{x}$ films whose 
absorption activity not only was shifted toward the longer visible wavelength but also had higher thermal stability and less recombination centers of charge carries than the metaldoped $\mathrm{TiO}_{2}$ [5]. However, to date, little research has been conducted on gaining in-depth information on the properties of the interstitial (or substitutional) $\mathrm{N}$-doped $\mathrm{TiO}_{2}$, as well as its photocatalytic activity. Different dopants result in $\mathrm{TiO}_{2}$ of different properties and consequently alter the photocatalytic activity of the materials. Currently, few works have focused on the synergistic effects of nitrogen dopant and calcination temperature on the characteristics and visible-light-induced photoactivity of $\mathrm{N}$-doped $\mathrm{TiO}_{2}$ [6].

In this study, we focused on sol-gel synthesis process for the preparation of nitrogen-doped $\mathrm{TiO}_{2}$ catalysts $\left(\mathrm{N}-\mathrm{TiO}_{2}\right)$ because the wet processes have the advantages of low cost, ease of scale-up, and stablility for practical applications. The effects of $\mathrm{N}$ atom and calcination temperature on the structural, optical, and photocatalytic properties of $\mathrm{N}-\mathrm{TiO}_{2}$ were assessed. The gel samples were calcined at 400, 500, 600, 700, and $800^{\circ} \mathrm{C}$. The photocatalysts were characterized using Xray diffraction (XRD), high-resolution transmission electron microscope (HRTEM), X-ray photoelectron spectroscopy (XPS), UV-vis diffusion reflectance spectroscopy (UV-vis DRS), Brunauer-Emmett-Teller (BET) specific surface area $\left(S_{\mathrm{BET}}\right)$, and thermogravimetric-differential thermal analysis (TG-DTA). The transition from amorphous to anatase and rutile phases at different calcination temperatures was also explored. Ethylene was chosen as a probe reactant because it is structurally simple, has relatively high reactivity, and is the parent compound of many widespread volatile organic compounds (VOCs) of environmental concern (e.g., TCE and tetrachloroethylene). The object of this study is to investigate the synergistic effects of nitrogen content and calcination temperatures in the synthesis process of $\mathrm{N}$-doped $\mathrm{TiO}_{2}$ prepared by sol-gel process and to investigate the influence of ethylene on photocatalytic decomposition.

\section{Materials and Methods}

2.1. Preparation of $\mathrm{N}$-Doped $\mathrm{TiO}_{2}$ Catalyst. Titanium isopropoxide (TTIP, $\mathrm{C}_{12} \mathrm{H}_{28} \mathrm{O}_{4} \mathrm{Ti}, 97 \%$, Aldrich), a highly reactive alkoxide, was used as precursor. Aqua ammonia $\left(\mathrm{NH}_{4} \mathrm{OH}\right)$ was used as nitrogen source. A given amount of aqua ammonia was added to the distilled water while being stirred until it completely dissolved at room temperature. Then, the solution was added dropwise to a constant amount of titanium isopropoxide as to obtain an aqua ammonia to TTIP molar ratio $(\mathrm{A} / \mathrm{T})$ of $1: 1$; the $\mathrm{TiO}_{2}$ sample was designated as $\mathrm{N}-\mathrm{TO}_{2}$. While the mixture was being stirred vigorously, the urea solution was introduced to the TTIP. Hydrolysis and ploycondensation reactions occurred. The reactant was stirred continuously for one hour after all aqua ammonia solution was dissipated. The sol was aged in air for $24 \mathrm{hr}$ to allow further hydrolysis. The final sol was left on the bench top to allow thickening. After aging, the sol was dried at $70^{\circ} \mathrm{C}$ for $24 \mathrm{hr}$ to evaporate the solvent. The residual xerogel was crushed to fine powder before calcined in a furnace at $400,500,600,700$, and $800^{\circ} \mathrm{C}$, respectively, for $3 \mathrm{hr}$. Pure
$\mathrm{TiO}_{2}$ powder was also prepared without the presence of aqua ammonia following the same procedures as described above. The nitrogen-doped samples were labeled $\mathrm{A} x \mathrm{~T} y$, where $x$ and $y$ refer to the aqua ammonia to TTIP molar ratio (A/T) and calcining temperature, respectively. For example, A20T4 means the $\mathrm{N}-\mathrm{TiO}_{2}$ prepared with A/T molar ratio 2.0 and calcinated at $400^{\circ} \mathrm{C}$.

2.2. Characterization. The $S_{\mathrm{BET}}$ of the samples was determined using nitrogen adsorption method measured with a Micromeritics ASAP 2020 adsorption apparatus. Pore size and pore volume were calculated by the $\mathrm{BJH}$ isotherm. The crystallization behavior and stability of $\mathrm{N}$ atoms in $\mathrm{N}-\mathrm{TiO}_{2}$ were monitored using a TG-DTA (STA 6000, PerkinElmer), while the sample was being heated from room temperature to $1000^{\circ} \mathrm{C}$ at $10^{\circ} \mathrm{C} / \mathrm{min}$. The morphology, structure, and grain size of the samples were characterized by a high-resolution transparent electromicroscopy (HRTEM, JEM-2010, JEOL). To study the optical response of $\mathrm{N}^{-\mathrm{TiO}_{2}}$ samples $(\lambda=200-$ $800 \mathrm{~nm}$ ), UV-vis DRS (U3900H, Hitachi) were recorded using a spectrophotometer with an integrating sphere attachment and $\mathrm{Al}_{2} \mathrm{O}_{3}$ was used as the reference. The chemical environment information and the $\mathrm{N}$ concentration of all of the samples were measured by X-ray photoelectron spectra (XPS) (PHI 5000, VersaProbe/Scanning ESCA Microprobe with a $\mathrm{C}_{60}$ ion gun). All samples were collected in vacuum and transferred to the main ultrahigh-vacuum (UHV) chamber for measurements. The shift of binding energy due to relative surface charging was corrected to the $\mathrm{C} 1 \mathrm{~s}$ level at $285 \mathrm{eV}$ as an internal standard. The XPS peaks were assumed to have Gaussian line shapes and were resolved into components by a nonlinear least-squares procedure after proper subtraction of the baseline. The crystallinity and phase of the samples were analyzed by XRD (PANalytical X'Pert-Pro MPD PW3040/60) with $\mathrm{Cu}-\mathrm{Ka}$ radiation at a scan rate of $0.05^{\circ} 1 / \mathrm{s}$ in the range from 20 to $80^{\circ}$.

\subsection{Photooxidation Performance. The experiment setup and} operating conditions for photocatalytic activity tests were the same as those reported previously [7]. The catalyst was prepared by depositing suspension of the as-prepared catalyst at the bottom surface of the reactor that was subsequently dried at ambient condition. The obtained catalyst film density on the bottom surface of reactor was kept at $4 \mathrm{mg} / \mathrm{cm}^{2}$. The experiment setup and operating conditions for photocatalytic activity tests were the same as those in our previous reports [7]. The photocatalytic activity experiments of the as-prepared catalysts for the oxidation of ethylene in gas phase were performed at room temperature using a $250 \mathrm{~mL}$ photocatalytic reactor. Air with $60 \%$ relative humidity was passed through the reactor with the sample inside for $1 \mathrm{hr}$ to reach equilibrium, and then a desired amount of ethylene was injected into the reactor with a gastight syringe. The ethylene inside the reactor was taken at regular intervals with gas-tight syringe and analyzed using gas chromatographs (PerkinElmer, Clarus 500, USA) equipped with a flame ionization detector (FID) and a thermal conductivity detector (TCD) detection. The GC instrument was equipped with an 
Elite-Plot-Q capillary column (Agilent Technologies). The ethylene was allowed to reach adsorption equilibrium with the catalyst in the reactor prior to irradiation. Two 500W horizontal halogen lamps ( $9.5 \mathrm{~cm}$ in length, PHILIPS) were used to simulate the solar light. The lamp equipped with a cut-off filter $(\lambda>400 \mathrm{~nm})$ was vertically placed outside the photocatalytic reactor. Light intensity at the catalyst surface was $16 \mathrm{~mW} / \mathrm{cm}^{2}$. Blank experiments using an uncoated (no catalyst) glass plate had no effect on the ethylene concentration and did not generate any carbon monoxide or carbon dioxide (see supplementary material online at http://dx.doi.org/10.1155/2013/268723). The photocatalytic activity of the catalyst can be quantitatively evaluated by comparing the apparent reaction rate constants.

\section{Results and Discussion}

3.1. Thermal Analysis. To investigate the process of phase transformation of titanium(IV)-oxide-hydroxide to titanium oxide and the effect of nitrogen doping content on the transformation from anatase to rutile, thermoanalytic techniques including TGA and DTA were conducted. Typically, the hydrothermal weight loss is attributed to a multistep of polycondensation of titanium(IV)-oxide-hydroxide and phase transformation of anatase into rutile or brookite from room temperature to $700-800^{\circ} \mathrm{C}$ as shown in Figure 1 and Table 1. DTA measurements established the transformation of $\mathrm{TiO}_{x}(\mathrm{OH})_{y}$ into $\mathrm{TiO}_{2}$ including two endothermic and one exothermic peaks from room temperature to $398^{\circ} \mathrm{C}$ (Figure 1). A sharp endothermic peaks at $105^{\circ} \mathrm{C}$ due to the release of absorbed water, while the other minor peak at $253^{\circ} \mathrm{C}$ is referred to as the desorption of organic. There was a corresponding weight loss from TGA of about 19.8 and $9.4 \mathrm{wt} \%$, respectively. In the region mentioned above, the finely exothermic peak around $276^{\circ} \mathrm{C}$ is ascribed to the thermal decomposition of unhydrolyzed TTIP with about $0.8 \mathrm{wt} \%$ weight loss. The weak thermal effect at $276-730^{\circ} \mathrm{C}$ is accompanied by obvious exothermic peak at $451^{\circ} \mathrm{C}$ which can be assigned to the crystallization of the amorphous phase to anatase. At around $730^{\circ} \mathrm{C}$, an obvious exothermic peak was observed owing to the oxidation of carbon residue and evaporation of chemisorbed water, which can be assigned to the phase transformation from anatase titania to rutile $\mathrm{TiO}_{2}$. It can be concluded from the DTA result that the asprepared $\mathrm{TiO}_{2}$ sample was amorphous. According to TGA, the weight loss roughly consists of three distinct stages. The first stage was up to $276^{\circ} \mathrm{C}$, over which the mass loss is the greatest. A mass loss of up to $30 \%$ was observed, which is attributed to the evaporation of the physical adsorbed water and the release of organic. The second stage is from 276 to $451^{\circ} \mathrm{C}$, where the mass loss is about $1.7 \%$. This corresponds to the thermal decomposition of unhydrolyzed TTIP. The third stage is from 451 to $730^{\circ} \mathrm{C}$ and the mass loss is about $0.7 \%$, which is attributed to the removal of chemisorbed water. At about $730^{\circ} \mathrm{C}$, no mass loss was observed. The exothermic peaks of $\mathrm{N}-\mathrm{TiO}_{2}$ prepared at $0.5,1.0$, and $2.0 \mathrm{~A} / \mathrm{T}$ ratios were at 710,720 , and $730^{\circ} \mathrm{C}$, respectively (Table 1 ). The results indicated that nitrogen atoms doped in $\mathrm{TiO}_{2}$ could prevent

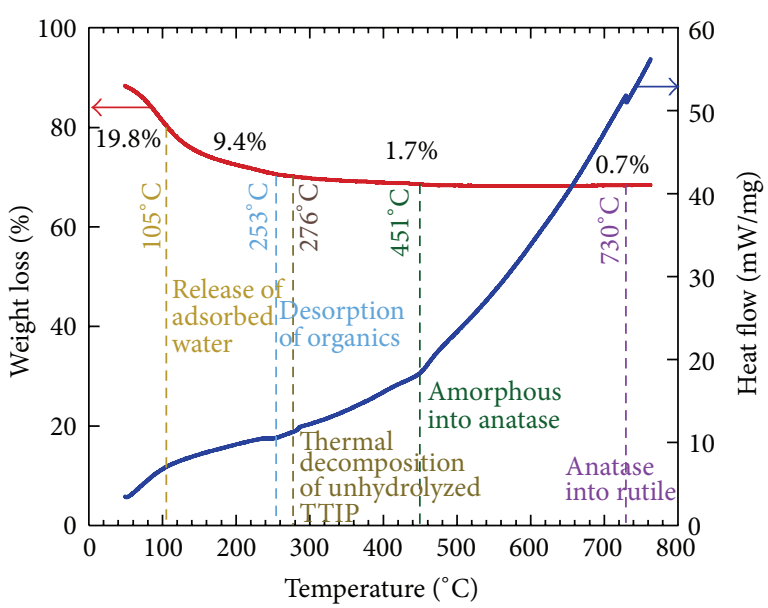

Figure 1: TG-DTA curve of $\mathrm{N}^{-\mathrm{TiO}_{2}}$ samples prepared with 2.0 ammonia/TTIP ratio.

phase transition of anatase to rutile, because as far as pure $\mathrm{TiO}_{2}$ was concerned, most $\mathrm{TiO}_{2}$ particles were transformed into rutile at $700^{\circ} \mathrm{C}$.

3.2. Phase and Structure. The characteristics of $\mathrm{N}-\mathrm{TiO}_{2}$ at various calcination temperatures and molar ratios of $\mathrm{A} / \mathrm{T}$ are summarized in Table 1. Figure 2 shows the XRD pattern of the $\mathrm{N}-\mathrm{TiO}_{2}$ samples at various $\mathrm{A} / \mathrm{T}$ ratios and annealed at different temperatures. The presence of peaks $(2 \theta=$ $25.44^{\circ}, 38.06^{\circ}$, and $48.24^{\circ}$ ) was regarded as an attributive indicator of anatase titania, and the presence of peaks $(2 \theta=$ $27.54^{\circ}, 36.14^{\circ}$, and $41.20^{\circ}$ ) was regarded as an attributive indicator of rutile titania. The diffraction peaks for the anatase (JCPDS no. 21-1272) and rutile (JCPDS no. 21-1276) phases are marked with "A" and "R," respectively, and the corresponding diffraction planes are given in parenthesis. No N-derived peaks were detected in all the patterns. This may be caused by the lower concentration of the doped species, and the limited dopants may have moved into either the interstitial positions or the substitutional sites of the $\mathrm{TiO}_{2}$ crystal structure, which is consistent with $[8,9]$. The average grain size was estimated at $28-131 \mathrm{~nm}$, comparable to that from the HRTEM image. A comparison of XRD patterns clearly shows that nitrogen doping significantly changes the crystalline size and the crystal structure of $\mathrm{TiO}_{2}$.

The transformation from the amorphous to the crystalline form of $\mathrm{TiO}_{2}$ usually requires temperatures close to $300^{\circ} \mathrm{C}[8]$. For the samples prepared with $2.0 \mathrm{~A} / \mathrm{T}$ and calcinated at $400-500^{\circ} \mathrm{C}$ (Figure $2(\mathrm{a})$ ), the intensities of the anatase peak are increased and the width of the (101) plane diffraction peak becomes narrower as the calcination temperature increases, implying an improvement and growth in crystallinity. Increasing the temperature to $800^{\circ} \mathrm{C}$, the intensity of anatase peak decreases, but the rutile peaks appear, suggesting the transformation of anatase to rutile phase. The average crystalline size was 32,85 , and $103 \mathrm{~nm}$ and the mass percentage of anatase was 90,60 , and $6 \%$ for samples prepared at $2.0 \mathrm{~A} / \mathrm{T}$ and calcination temperature 
TABLE 1: Characteristics for $\mathrm{N}-\mathrm{TiO}_{2}$ at various ammonia/TTIP molar ratios under different calcination temperatures.

\begin{tabular}{|c|c|c|c|c|c|c|c|c|c|c|c|}
\hline \multirow{3}{*}{ Sample ${ }^{\mathrm{a}}$} & \multicolumn{4}{|c|}{ XRD } & \multirow{3}{*}{$\begin{array}{c}\text { BET } \\
\text { Surface area }\left(\mathrm{m}^{2} / \mathrm{g}\right)\end{array}$} & \multirow{3}{*}{$\begin{aligned} & \text { TG-DTA } \\
\rightarrow & \mathrm{R}^{\mathrm{c}} \text { Temp. }\left({ }^{\circ} \mathrm{C}\right)\end{aligned}$} & \multirow{3}{*}{$\begin{array}{c}\text { TEM } \\
\text { Size }(\mathrm{nm})\end{array}$} & \multicolumn{4}{|c|}{ Optical properties } \\
\hline & \multicolumn{2}{|c|}{ Phase ratio } & \multicolumn{2}{|c|}{ Crystallite size } & & & & $\lambda_{g, 1}$ & $E_{g, 1}$ & $\lambda_{g, 2}$ & $E_{g, 2}$ \\
\hline & $\mathrm{A}^{\mathrm{b}} \%$ & $\mathrm{R}^{\mathrm{c}} \%$ & $\mathrm{~A}^{\mathrm{b}}(\mathrm{nm})$ & $\mathrm{R}^{\mathrm{c}}(\mathrm{nm})$ & & & & $(\mathrm{nm})$ & $(\mathrm{nm})$ & $(\mathrm{nm})$ & $(\mathrm{nm})$ \\
\hline A00T4 & 90 & 10 & 32 & - & 93 & 703 & $11 \pm 1$ & 392 & 3.16 & - & - \\
\hline A05T4 & 89 & 11 & 28 & - & 108 & 710 & $12 \pm 1$ & 392 & 3.16 & 505 & 2.46 \\
\hline $\mathrm{A} 10 \mathrm{~T} 4$ & 90 & 10 & 28 & - & 119 & 720 & $12 \pm 1$ & 391 & 3.17 & 506 & 2.45 \\
\hline A15T4 & 87 & 13 & 29 & - & 119 & 728 & $11 \pm 1$ & 388 & 3.20 & 513 & 2.42 \\
\hline A20T4 & 90 & 10 & 32 & - & 98 & 730 & $12 \pm 1$ & 390 & 3.18 & 510 & 2.43 \\
\hline $\mathrm{A} 25 \mathrm{~T} 4$ & 90 & 10 & 37 & - & 98 & 728 & $12 \pm 1$ & 392 & 3.16 & 515 & 2.41 \\
\hline A30T4 & 92 & 8 & 37 & - & 86 & 729 & $12 \pm 1$ & 392 & 3.16 & 514 & 2.41 \\
\hline A00T5 & 94 & 6 & 46 & - & 50 & 703 & $13 \pm 2$ & 402 & 3.08 & - & - \\
\hline A05T5 & 89 & 11 & 46 & 98 & 64 & 710 & $13 \pm 1$ & 404 & 3.07 & 503 & 2.47 \\
\hline A10T5 & 90 & 10 & 41 & 87 & 68 & 720 & $15 \pm 2$ & 400 & 3.10 & 508 & 2.44 \\
\hline A15T5 & 91 & 9 & 40 & - & 71 & 728 & $15 \pm 2$ & 396 & 3.13 & 517 & 2.40 \\
\hline A20T5 & 94 & 6 & 45 & - & 62 & 730 & $15 \pm 2$ & 394 & 3.15 & 513 & 2.42 \\
\hline A25T5 & 94 & 6 & 49 & - & 55 & 728 & $17 \pm 2$ & 397 & 3.12 & 507 & 2.45 \\
\hline A30T5 & 94 & 6 & 47 & - & 53 & 729 & $17 \pm 2$ & 397 & 3.12 & 510 & 2.43 \\
\hline A00T6 & 34 & 66 & 106 & 156 & 7 & 703 & $24 \pm 2$ & 420 & 2.95 & - & - \\
\hline A05T6 & 14 & 86 & 86 & 128 & 8 & 710 & $40 \pm 3$ & 422 & 2.94 & - & - \\
\hline A10T6 & 14 & 86 & 81 & 132 & 9 & 720 & $40 \pm 4$ & 425 & 2.92 & - & - \\
\hline A15T6 & 22 & 78 & 79 & 141 & 14 & 728 & $35 \pm 3$ & 424 & 2.92 & - & - \\
\hline A20T6 & 60 & 40 & 85 & 184 & 17 & 730 & $34 \pm 3$ & 415 & 2.99 & - & - \\
\hline A25T6 & 78 & 22 & 90 & 184 & 16 & 728 & $35 \pm 4$ & 416 & 2.98 & - & - \\
\hline A30T6 & 74 & 26 & 97 & 169 & 12 & 729 & $36 \pm 4$ & 415 & 2.99 & - & - \\
\hline A00T7 & 6 & 94 & 131 & 177 & 2 & 703 & $80 \pm 5$ & 424 & 2.92 & - & - \\
\hline A05T7 & 3 & 97 & 95 & 148 & 5 & 710 & $145 \pm 10$ & 428 & 2.90 & - & - \\
\hline A10T7 & 3 & 97 & 102 & 149 & 6 & 720 & $145 \pm 10$ & 429 & 2.89 & - & - \\
\hline A15T7 & 3 & 97 & 92 & 159 & 6 & 728 & $150 \pm 11$ & 428 & 2.90 & - & - \\
\hline A20T7 & 6 & 94 & 103 & 163 & 4 & 730 & $170 \pm 13$ & 428 & 2.90 & - & - \\
\hline A25T7 & 15 & 85 & 108 & 178 & 8 & 728 & $60 \pm 6$ & 426 & 2.91 & - & - \\
\hline A30T7 & 15 & 85 & 117 & 182 & 6 & 729 & $60 \pm 6$ & 427 & 2.90 & - & - \\
\hline A00T8 & 1 & 99 & - & 174 & 3 & 703 & $200 \pm 17$ & 424 & 2.92 & - & - \\
\hline A05T8 & 1 & 99 & - & 161 & 3 & 710 & $190 \pm 15$ & 428 & 2.90 & - & - \\
\hline A10T8 & 1 & 99 & - & 159 & 3 & 720 & $160 \pm 13$ & 429 & 2.89 & - & - \\
\hline A15T8 & 1 & 99 & - & 171 & 3 & 728 & $170 \pm 15$ & 428 & 2.90 & - & - \\
\hline A20T8 & 1 & 99 & - & 164 & 2 & 730 & $160 \pm 14$ & 428 & 2.90 & - & - \\
\hline A25T8 & 3 & 97 & 106 & 184 & 4 & 728 & $200 \pm 18$ & 427 & 2.90 & - & - \\
\hline А30T8 & 3 & 97 & 127 & 179 & 3 & 729 & $170 \pm 15$ & 429 & 2.89 & - & - \\
\hline
\end{tabular}

${ }^{\mathrm{a}} \mathrm{AXXTY}$ : ammonia/TTIP molar ratio $=0 . X X$; calcination temperature $=Y 00^{\circ} \mathrm{C}$.

${ }^{\mathrm{b}}$ Anatase.

${ }^{\mathrm{c}}$ Rutile.

of 400,600 , and $700^{\circ} \mathrm{C}$, respectively. The maximum mean size of anatase and rutile crystallites was observed at $800^{\circ} \mathrm{C}$. Results agreed with those reported that the crystalline size grows and the content of anatase diminishes as calcination temperature increases $[8,10-13]$. For the samples prepared at $0.5 \mathrm{~A} / \mathrm{T}$, the anatase peaks appear at temperatures 400 and $500^{\circ} \mathrm{C}$. Increasing the temperature to $500^{\circ} \mathrm{C}$, the intensity of anatase peak decreases, but the rutile peaks appear. When temperature is increased further to $600^{\circ} \mathrm{C}$, rutile becomes a main phase. In this case, the anatase-to-rutile phase transformation temperature is between 400 and $500^{\circ} \mathrm{C}$. XRD patterns of samples prepared at 3.0 $\mathrm{A} / \mathrm{T}$ and annealed at $700^{\circ} \mathrm{C}$ show both anatase and a rutile phase, indicating that anatase-to-rutile phase transformation is shifted to higher temperature. It can be seen that the presence of nitrogen can restrain the formation and growth of $\mathrm{TiO}_{2}$ crystal phase, thereby retarding the anatase-to-rutile phase transformation. This result is further supported by the appearance of rutile in XRD patterns of sample prepared at 0.5 and $1.5 \mathrm{G} / \mathrm{T}$ at $600^{\circ} \mathrm{C}$ and disappearance for samples prepared at $\mathrm{G} / \mathrm{T}$ greater than 2.0 at $600^{\circ} \mathrm{C}$ (data not shown). Compared with P25, the peak position of the (101) plane of N-doped 


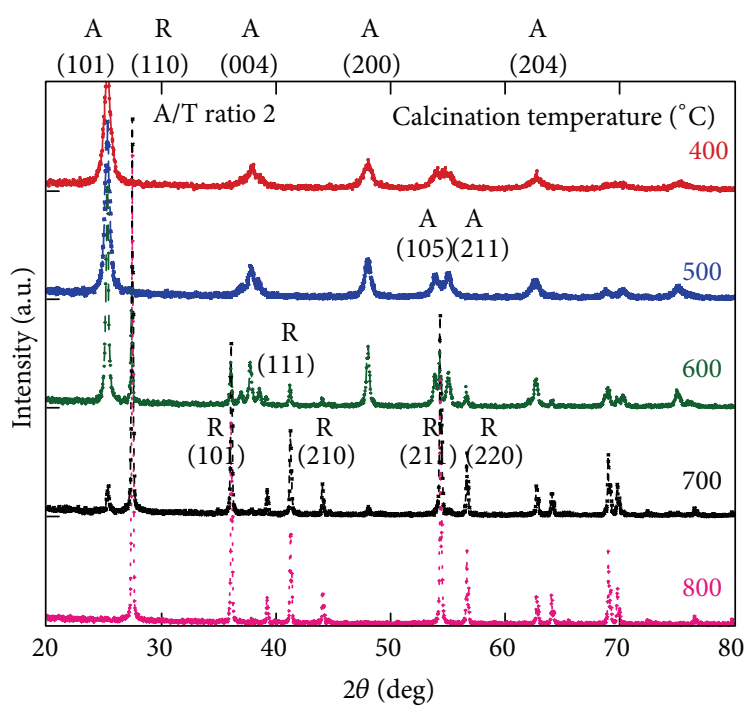

(a)

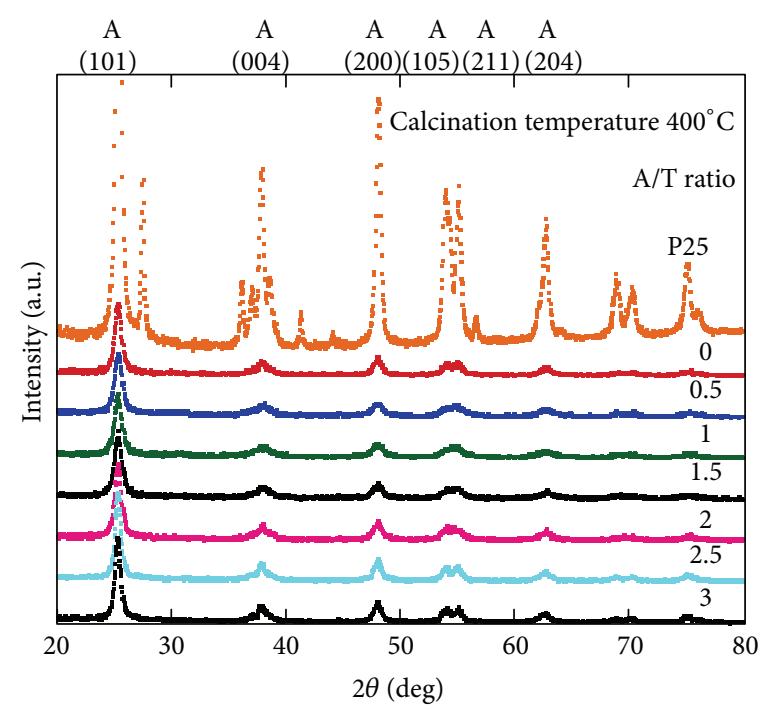

(b)

FIGURE 2: XRD patterns of $\mathrm{N}-\mathrm{TiO}_{2}$ samples prepared (a) at various calcination temperatures and (b) with various ammonia/TTIP ratios.

$\mathrm{TiO}_{2}$ shifted slightly to higher $2 \theta$ value, and the peak was broader as N/T ratio increases, suggesting distortion of the crystal lattice of $\mathrm{TiO}_{2}$ by the incorporation of nitrogen. The crystalline sizes of samples calcinated at $400^{\circ} \mathrm{C}$ and prepared at $0.5,1.5,2.0$, and $3.0 \mathrm{~A} / \mathrm{T}$ were $28,29,32$, and $37 \mathrm{~nm}$, respectively. The average crystalline size of samples increases with increase in $\mathrm{A} / \mathrm{T}$, revealing that nitrogen can enhance the growth of $\mathrm{N}-\mathrm{TiO}_{2}$ crystals. Results agreed with those reported that the crystalline size grows as nitrogen to Ti proportion increases [14]. The results reveal that the phase transformation temperature of anatase to rutile was progressively increased when the amount of $\mathrm{N}$ dopant was increased. Clearly, calcination temperature and $\mathrm{A} / \mathrm{T}$ ratio play a significant role in the formed crystal structure and particle size (Figure 3). Higher temperature favors the growth of rutile structure and produces $\mathrm{N}-\mathrm{TiO}_{2}$ nanoparticles with larger particle size. Thus, a fine control of calcination temperature and $\mathrm{A} / \mathrm{T}$ ratio is crucial for obtaining a pure phase of $\mathrm{N}-\mathrm{TiO}_{2}$.

Further insights into the effect of calcination and doping on the morphology and structure of the $\mathrm{N}-\mathrm{TiO}_{2}$ samples can be obtained from HRTEM image (Figure 4). The selected area electron diffraction pattern and TEM confirmed its highly crystalline anatase or rutile structure. The observed $d$-spacing from HRTEM image is $3.522 \AA$ and is comparable to $3.52 \AA$ previously reported for (101) crystallographic plane of undoped anatase [15-18]. The HRTEM image showed the nanocrystallines with primary grain size around 11$200 \mathrm{~nm}$. From the TEM images, the particles in $\mathrm{N}_{-} \mathrm{TiO}_{2}$ samples are monodispersed. The crystalline form aggregates with a mesoporous structure. The formation of mesoporous structure is similar to that reported in the literature [19, 20]. First, monodispersed amorphous titanium oxide sol particles are formed by the hydrolysis processes. Then the monodispersed sol particles are crystallized and aggregated under calcination treatment to form mesoporous crystalline. Based on the HRTEM results, the calcination temperature

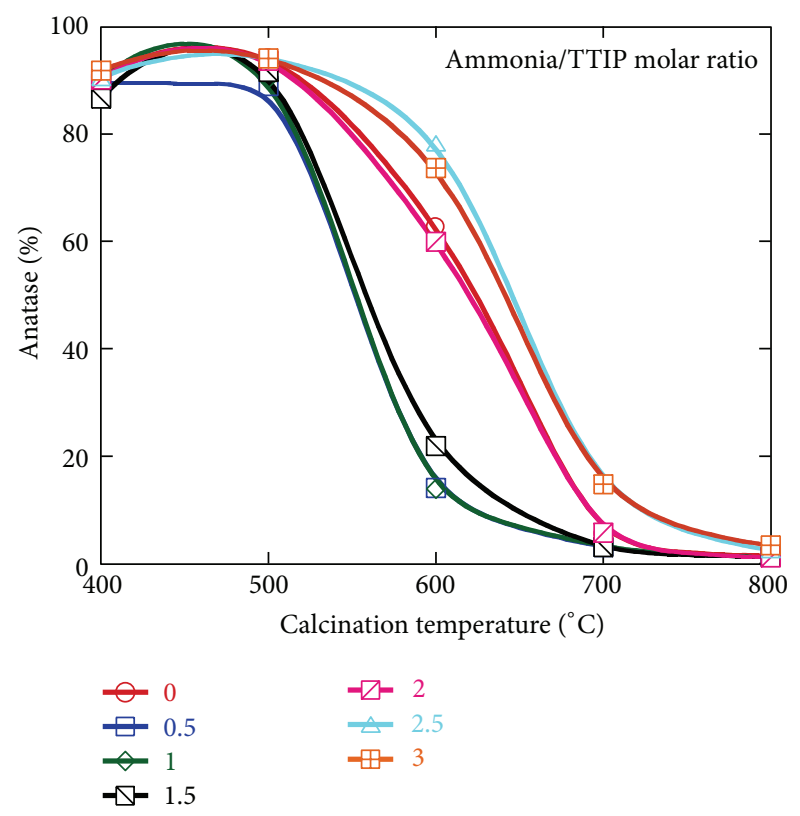

FIgURE 3: The anatase content of $\mathrm{N}-\mathrm{TiO}_{2}$ samples as a function of the various ammonia/TTIP molar ratios.

significantly changes the size of particles (Table 1). The grain size of crystalline is in consistent with the calculated value obtained from XRD patterns (Table 1). The grain size of samples increases with the calcination temperature. Morphological observation by TEM and XRD calculations reveals that the large particle size of A20T8 was mainly caused by agglomeration and the growth of crystallite size.

3.3. Surface Area and Pore Size Distribution. Typical nitrogen adsorption-desorption isotherms of $\mathrm{N}-\mathrm{TiO}_{2}$ photocatalyst 


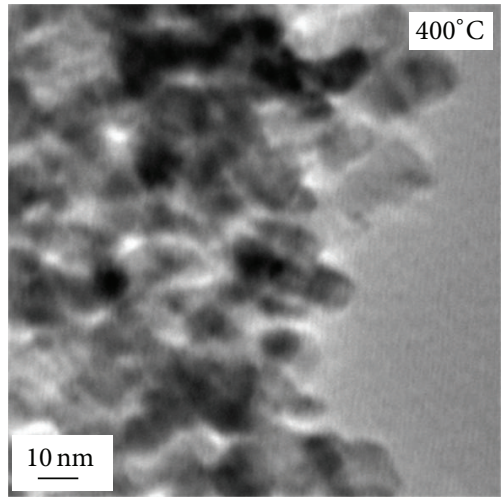

(a)

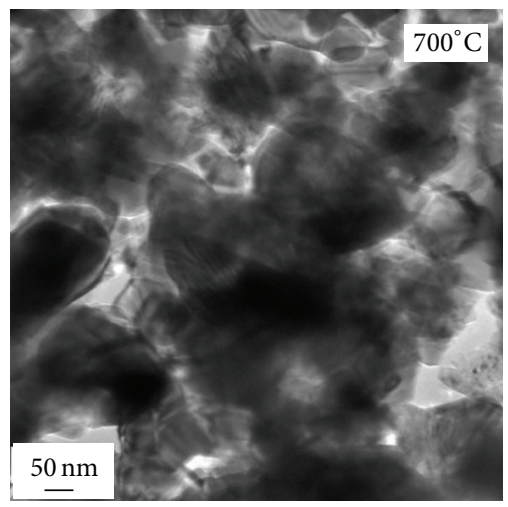

(d)

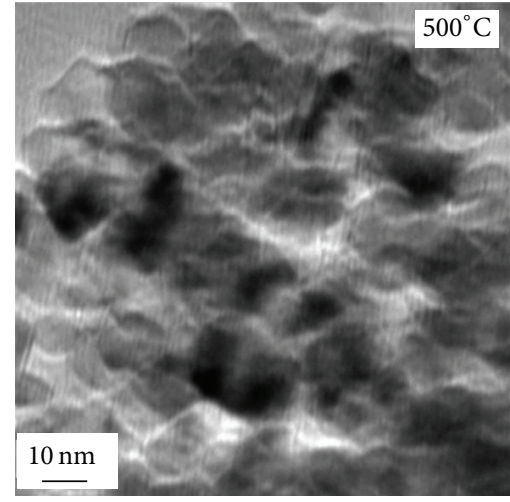

(b)

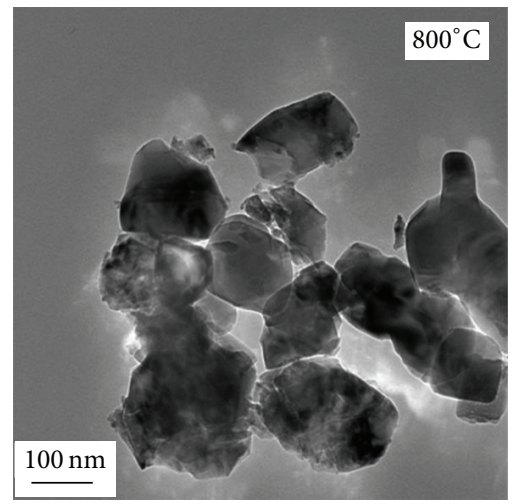

(e)

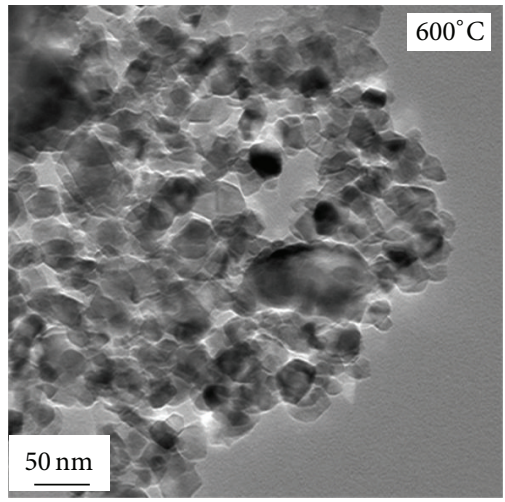

(c)

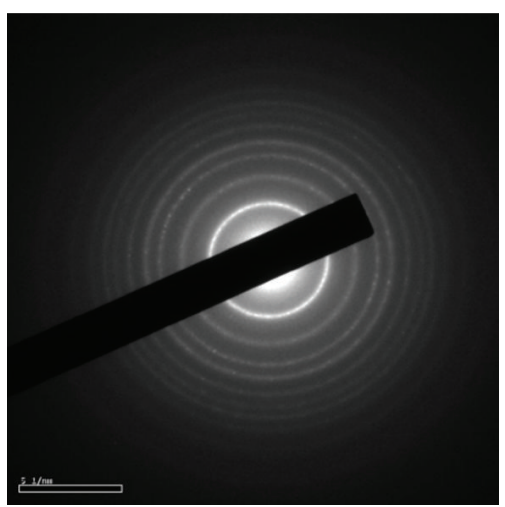

(f)

FIGURE 4: TEM images of $\mathrm{N}-\mathrm{TiO}_{2}$ prepared (a)-(e) at various calcination temperatures with 2.0 ammonia/TTIP ratio and (f) the selected area electron diffraction of A20T4.

are shown in Figure 5. The $S_{\mathrm{BET}}$ of $\mathrm{N}-\mathrm{TiO}_{2}$ prepared with 2.0 $\mathrm{A} / \mathrm{T}$ ratio at calcined $400,500,600,700$, and $800^{\circ} \mathrm{C}$ was 98 , $62,17,4$, and $2 \mathrm{~m}^{2} / \mathrm{g}$, respectively. Obviously, the values of $\mathrm{S}_{\mathrm{BET}}$ and pore volume of $\mathrm{N}-\mathrm{TiO}_{2}$ prepared with the same A/T ratio decreased with increasing calcination temperatures. Such phenomenon could be attributed to the collapse of the mesoporous structure, the growth of $\mathrm{TiO}_{2}$ crystallites, and the removal process of nitrogen core by high-temperature calcination. Consequently, $\mathrm{N}-\mathrm{TiO}_{2}$ calcined at $800^{\circ} \mathrm{C}$ has the least $S_{\mathrm{BET}}$. Based on the results obtained, the hysteresis loop of $\mathrm{N}-\mathrm{TiO}_{2}$ is significantly shifted in direction of higher relative pressures as calcination temperature increases, indicating much larger mesorpore. The average pore size of $\mathrm{N}-\mathrm{TiO}_{2}$ increased with increasing calcination temperature due to the formation of slit-like pores [21].

The $\mathrm{N}^{-}-\mathrm{TiO}_{2}$ samples obtained at various calcination temperatures gave different nitrogen adsorption isotherms (Figure 5), implying differences in their porous structure. The $\mathrm{N}-\mathrm{TiO}_{2}$ samples prepared at low calcination temperature (i.e., 400 and $500^{\circ} \mathrm{C}$ ) exhibited a type IV isotherm and a type $\mathrm{H} 2$ hysteresis loop at lower relative pressure region, which are typical characteristics of mesoporous structure with ink bottle pores. Note that the adsorption branches of these isotherms resembled type II, indicating the presence of some macropores. Otherwise the $\mathrm{N}-\mathrm{TiO}_{2}$ samples prepared at higher calcination temperature (i.e., $600-800^{\circ} \mathrm{C}$ ) exhibited a type $\mathrm{V}$ isotherm and a type $\mathrm{H} 3$ hysteresis loop at higher relative pressure. The hysteresis loop at lower relative pressure region $\left(0.4<P / P_{0}<0.8\right)$ was attributed to a smaller mesopore, while that at the higher relative pressure $(0.8<$ $\left.P / P_{0}<1.0\right)$ was of larger mesopores. Thus samples prepared at high calcination temperature $\left(>600^{\circ} \mathrm{C}\right)$ had a wide pore size distribution in the mesopores scale. The isotherm of $\mathrm{N}$ $\mathrm{TiO}_{2}$ prepared at higher calcination temperature was below that of lower calcination temperature (Figure 5), indicating lower surface area and pore volume of the former. Further observation from Table 1 indicated that $S_{\mathrm{BET}}$ for the $\mathrm{N}-\mathrm{TiO}_{2}$ samples at the same $\mathrm{A} / \mathrm{T}$ ratio increased with increasing calcination temperature (Figure 5(c)). Results reveal that all $\mathrm{N}-\mathrm{TiO}_{2}$ samples calcined at various temperatures show monomodal pore size distributions and mesopores may be assigned to the pores among interaggregated particles (data not shown). With calcination temperature increasing, there is a significant tendency of pore size distribution toward to the bigger pore size. The increase of pore size is due to the corruption of smaller pores during calcination as the smaller pores endured much greater stress than the bigger pores. Formation of bigger crystalline aggregation upon increase in temperature could form bigger pores also. Consequently, the pore size increases while the pore volume decreases with 


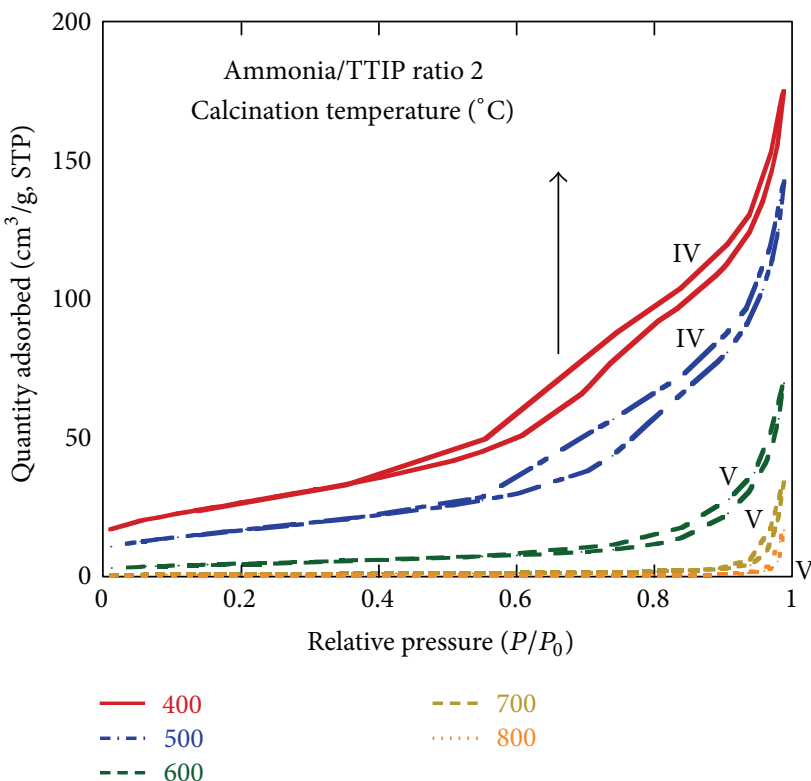

(a)

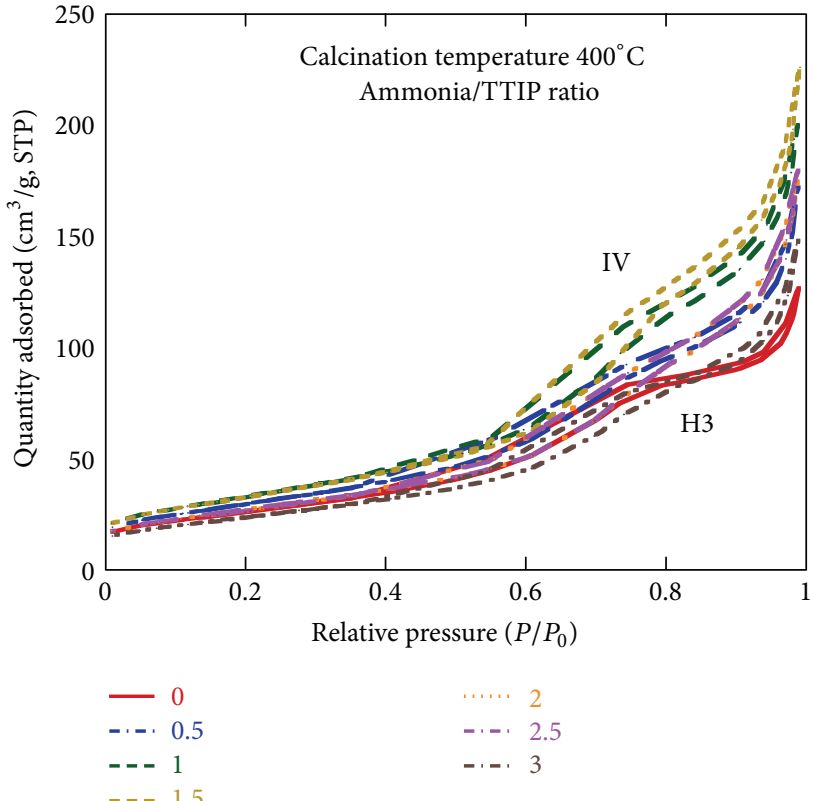

(b)

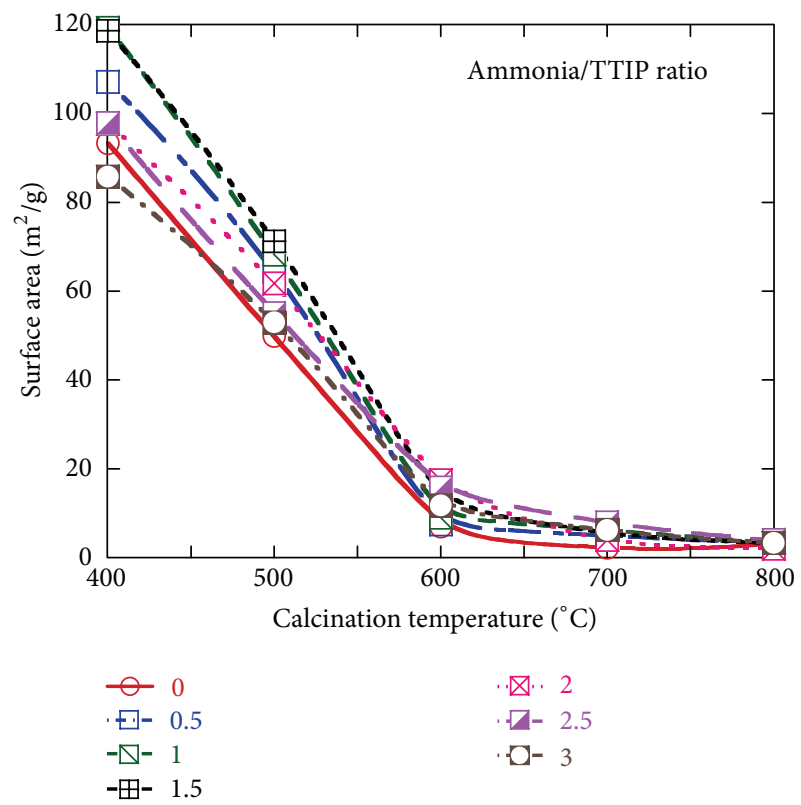

(c)

FIGURE 5: Nitrogen adsorption and desorption isotherms of $\mathrm{N}-\mathrm{TiO}_{2}$ samples (a) calcined at various temperatures, (b) prepared with various ammonia/TTIP molar ratios; the surface area as a function of calcination temperature.

calcinations temperature increasing. Based on the TEM and BET results, the mesopores of $\mathrm{TiO}_{2}$ were decreased due to the heat shrinkage of calcination. The results indicated that calcination at high temperature and in the presence of nitrogen atoms will help to improve the thermal stability of the photocatalyst. While the calcination temperature was increased, both the specific surface area and the pore volume of $\mathrm{N}-\mathrm{TiO}_{2}$ samples decreased. This indicated that the average pore size increased while the pore volume and the specific surface area decreased with calcination temperature increasing.

3.4. Optical Properties. The typical UV-vis diffuse reflectance spectra of $\mathrm{N}-\mathrm{TiO}_{2}$ are shown in Figures 6(a) and 6(b). It can be seen that nondoped $\mathrm{TiO}_{2}$ (P25) has only one light sharp edge $(\lambda=410 \mathrm{~nm})$ which can be assigned to the band gap of $\mathrm{TiO}_{2}$, while part of $\mathrm{N}-\mathrm{TiO}_{2}$ showed two absorption edges and a noticeable shift to the visible light region as compared 


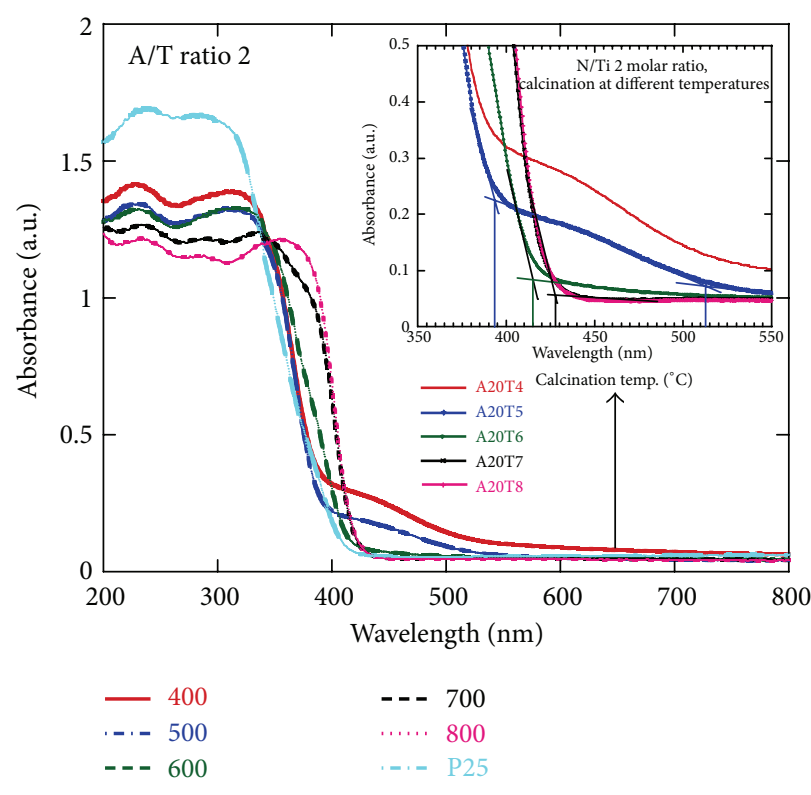

(a)

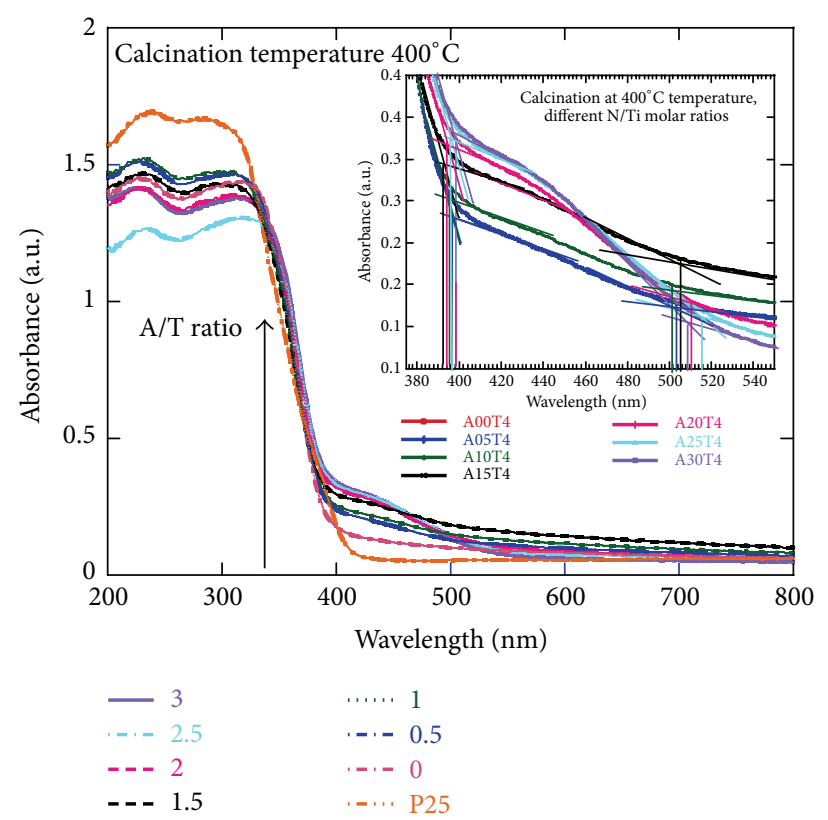

(b)

FIgURE 6: The typical UV-vis DR spectra of $\mathrm{N}^{-T i O}{ }_{2}$ samples: (a) prepared with 2.0 ammonia/TTIP molar ratio and calcined at various temperatures; (b) prepared with various ammonia/TTIP molar ratios and calcined at $400^{\circ} \mathrm{C}$.

to that of the $\mathrm{TiO}_{2}$ (i.e., P25). This phenomenon should be ascribed to either the nitrogen doping and/or sensitization by a surface-anchored group. The calcination temperature and $\mathrm{A} / \mathrm{T}$ ratio are the crucial factor that can further affect the absorption as seen in Figure 6. Similar phenomenon had been reported by previous publications [17, 22-25]. The absorption edges of the $\mathrm{N}-\mathrm{TiO}_{2}$ samples show continuous red shift as the calcination temperature changes from 400 to $700^{\circ} \mathrm{C}$, which can be assigned to the intrinsic band gap absorption of $\mathrm{TiO}_{2}$. The shift is too minor to be observed when the calcination temperature changes from 500 to $600^{\circ} \mathrm{C}$, which is possibly caused by the synergetic effect of the loss of the nitrogen and the increase of the $\mathrm{TiO}_{2}$ crystallinity during the calcination process. The absorption threshold $\left(\lambda_{g}\right)$ can be determined using the onset of the absorption edges by the section of the fitting lines on the upward and outward section of the spectrum (shown in the graph inserted in Figure 6) [23]. Table 1 lists the determined $\lambda_{g}(\mathrm{~nm})$ and the derived band gap energy values. The band gap of $\mathrm{N}-\mathrm{TiO}_{2}\left(E_{g}\right)$ was calculated using the $E_{g}=1240 / \lambda_{g}$ equation. It also can be seen that $\mathrm{N}-\mathrm{TiO}_{2}$ samples have two characteristic light absorption edges. One of them corresponds to the band gap of $\mathrm{TiO}_{2}\left(\lambda_{g 1}=390 \sim 430 \mathrm{~nm}\right)$ while the other originates from the $\mathrm{N}$-induced midgap level $\left(\lambda_{g 2}=505 \sim 517 \mathrm{~nm}\right)$. The color of the samples was different with calcination temperature and $\mathrm{A} / \mathrm{T}$ ratio. The color of $\mathrm{N}-\mathrm{TiO}_{2}$ samples prepared with $2.0 \mathrm{~A} / \mathrm{T}$ ratio and calcinated at 400,600 , and $700^{\circ} \mathrm{C}$ was vivid yellow, yellow, and white, respectively. There is no $\lambda_{g 2}$ when $\mathrm{N}-\mathrm{TiO}_{2}$ calcinated above $600^{\circ} \mathrm{C}$. It can be ascribed to the amount of $\mathrm{N}$ dopant decreased. The color of $\mathrm{N}-\mathrm{TiO}_{2}$ prepared with $0.0,1.0,2.0$, and $3.0 \mathrm{~A} / \mathrm{T}$ ratio and calcinated at $400^{\circ} \mathrm{C}$ was white, pale yellow, yellow, and vivid yellow, respectively. The phenomenon that the $\mathrm{A} / \mathrm{T}$ ratio increases the shifting of the spectra towards visible region was clearly observed (Figure 6(a)). The absorption threshold $\left(\lambda_{g}\right)$ was increased with increasing $\mathrm{A} / \mathrm{T}$ ratio. It reveals that more nitrogen doping in the matrix of $\mathrm{TiO}_{2}$ structure results in a shift of absorbance region toward visible light wavelength. This is possible attribute to the nitrogen incorporated into $\mathrm{TiO}_{2}$ lattice and formation of new electronic state above valence band caused by nitrogen doping to generate a red shift.

3.5. Analysis of Chemical State. The chemical states of doping impurity are critical to the optical property, band gap, and photocatalytic activity of nitrogen-doped $\mathrm{TiO}_{2}$. To investigate the chemical states of the doping nitrogen, XPS spectra were applied to examine three regions: the Ti $2 p$ core level near $460 \mathrm{eV}$, the $\mathrm{O} 1 \mathrm{~s}$ core level near $530 \mathrm{eV}$, and the $\mathrm{N}$ 1s core level near $400 \mathrm{eV}$. Figure 7 shows the experimental observation of surface chemical composition and the electronic structures of $\mathrm{N}-\mathrm{TiO}_{2}$ samples using XPS. XPS peaks showed that the N$\mathrm{TiO}_{2}$ contained only $\mathrm{Ti}, \mathrm{O}, \mathrm{N}$ elements and a small quantity of carbon. The presence of carbon was ascribed to the residual carbon from the precursor solution and the adventitious hydrocarbon from the XPS instrument itself. In Figures 7(a) and $7(\mathrm{~b})$, the binding energy (BE) peaks corresponding to $\mathrm{N}$ 1s core levels for $\mathrm{N}-\mathrm{TiO}_{2}$ are observed one major peak at $400 \mathrm{eV}$. The $\mathrm{N}$ 1s peak at $400 \mathrm{eV}$ is ascribed to the presence of the oxidized nitrogen species, and the nitrogen may be incorporating into the interstitial positions of the $\mathrm{TiO}_{2}$ lattice and to form a Ti-O-N structure $[26,27]$. No other $\mathrm{N}$ 1s peaks were detected in $\mathrm{N}_{-}-\mathrm{TiO}_{2}$ samples. As shown in Figure 7, $\mathrm{N}$ 1s peak at $400 \mathrm{eV}$ slightly decreased with increasing calcination 


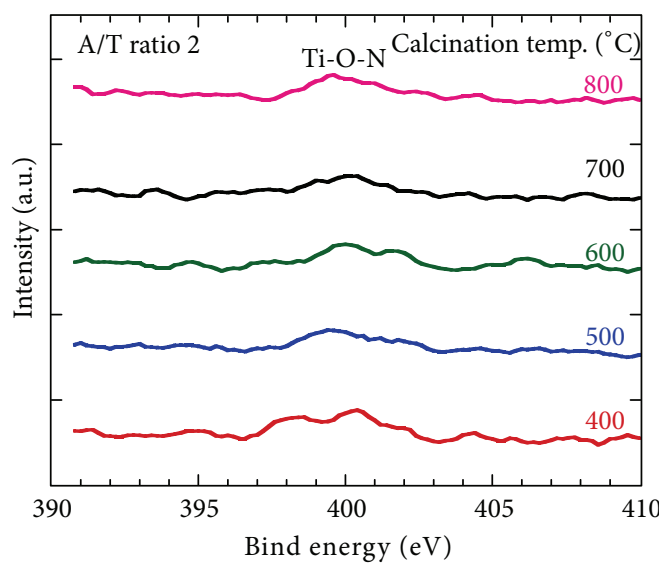

(a)

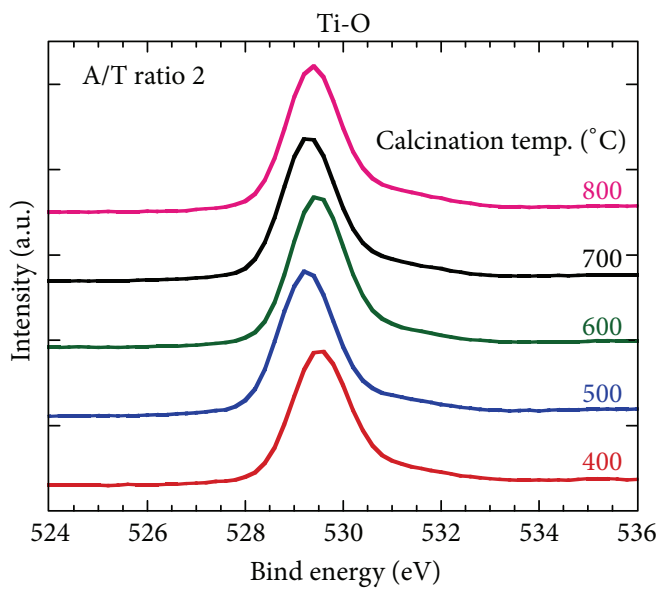

(c)

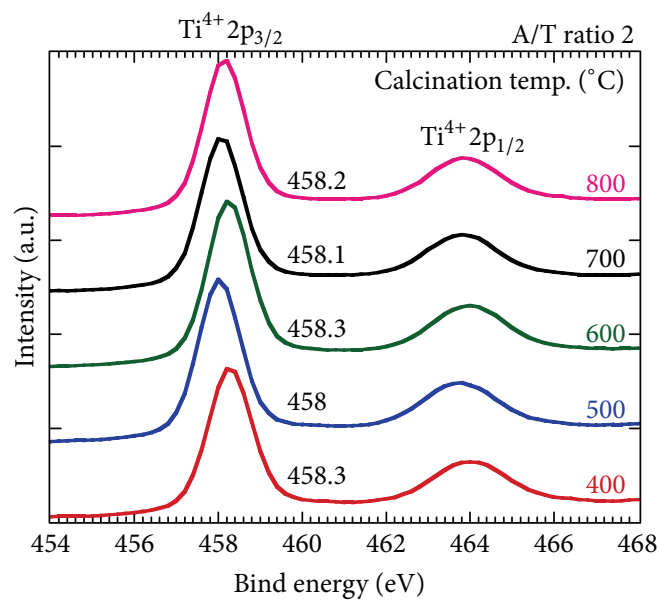

(e)

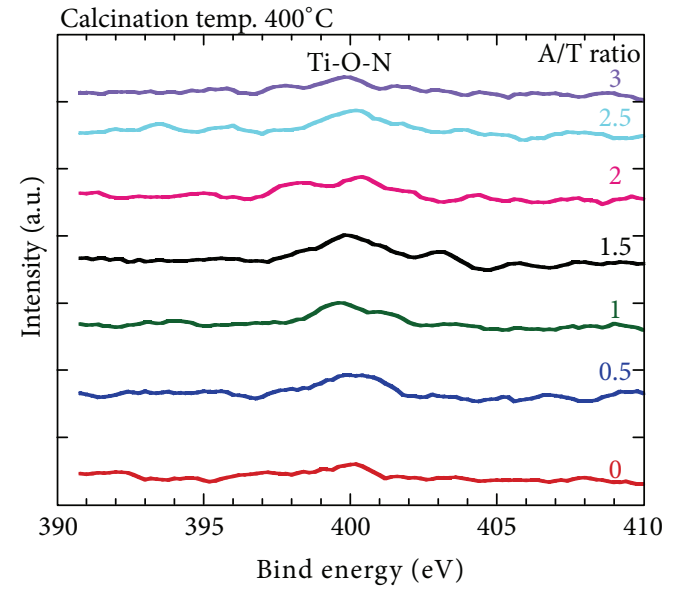

(b)

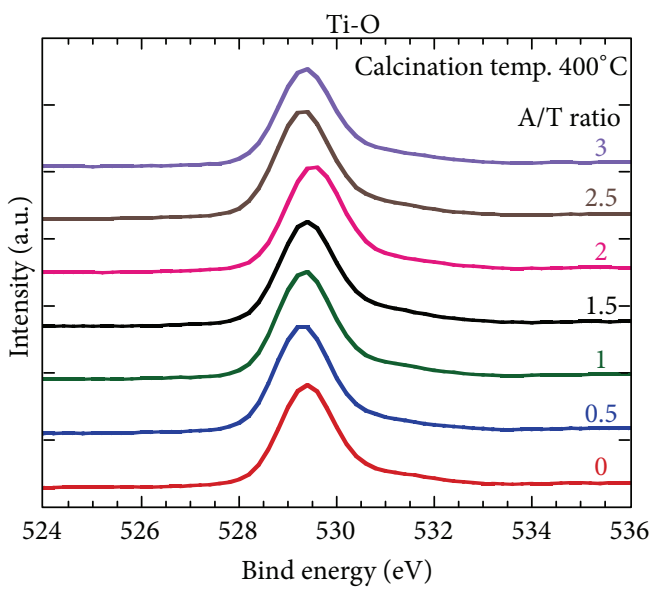

(d)

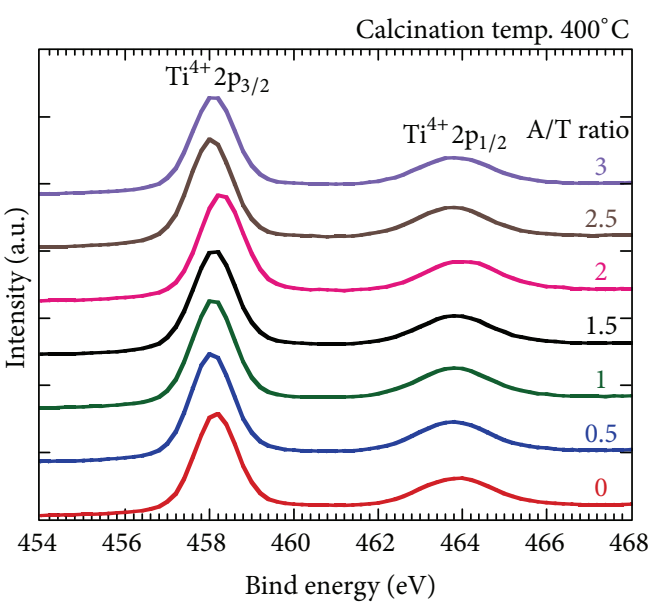

(f)

Figure 7: XPS survey and core level spectra of (a)-(b) N 1s, (c)-(d) Ti 2p, and (e)-(f) O 1s of N-TiO 2 samples.

temperature. This is different from the $\mathrm{N}-\mathrm{TiO}_{2}$ prepared by flame oxidation, in which nitrogen partially substitutes the oxygen sites in the $\mathrm{TiO}_{2}$ [28]. The preparation method plays an important role in determining the nitrogen state in $\mathrm{TiO}_{2}$ band structure $[26,29,30]$. Depending on the nitrogen source and experimental conditions $\mathrm{N}$ species are incorporated into $\mathrm{TiO}_{2}$ in interstitial form or substitutional form [31, 32]. The interstitial $\mathrm{N}$-doping is favored when the doping is carried out under oxygen-rich conditions and the substation-type $\mathrm{N}$ doping occurs under reducing conditions [31-33]. Therefore, 
from the atomic N 1s XPS spectra the interstitial sites $(400 \mathrm{eV})$ were observed under air atmosphere.

The XPS spectra of Ti $2 p$ regions are shown in Figures 7(c) and 7(d). The peaks at around 458.5 and $464.2 \mathrm{eV}$ for P25 are ascribed to Ti $2 \mathrm{p}_{3 / 2}$ and Ti $2 \mathrm{p}_{1 / 2}$ of $\mathrm{TiO}_{2}$ (data not shown). The line separation between $\mathrm{Ti} 2 \mathrm{p}_{1 / 2}$ and Ti $2 \mathrm{p}_{3 / 2}$ was $5.7 \mathrm{eV}$, which is consistent with the standard binding energy. According to Figure 7 , all spectra of Ti $2 \mathrm{p}_{1 / 2}$ are symmetry. The spectra of Ti $2 \mathrm{p}_{1 / 2}$ are consistent of single state and the banding energy of peaks is $458.0-458.3 \mathrm{eV}$ which shows a redshift of $0.5 \mathrm{eV}$ compared to the binding energy of $\mathrm{Ti}^{4+}$ in P25. This suggests that $\mathrm{Ti}^{3+}$ was present in $\mathrm{N}-\mathrm{TiO}_{2}$ and the distance of peaks between $\mathrm{Ti} 2 \mathrm{p}_{1 / 2}$ and $\mathrm{Ti} 2 \mathrm{p}_{3 / 2}$ is 5.7$5.9 \mathrm{eV}$. The $396 \mathrm{eV}$ peak is assigned to the atomic b-N state and generally proves the presence of TiAN bonds formed when $\mathrm{N}$ atoms replace the oxygen in the $\mathrm{TiO}_{2}$ crystal lattice [30]. The peak characteristic for $\mathrm{Ti}-\mathrm{N}(396 \mathrm{eV})$ is not present, indicating the absence of the TiN phase in the $\mathrm{N}^{-\mathrm{TiO}_{2}}$ samples [34]. The results show that the binding energies of $\mathrm{Ti}$ $2 \mathrm{p}$ peaks shift to lower energies with a negative shift of $\sim 0.5 \mathrm{eV}$ for the $\mathrm{N}-T i O_{2}$ due to the $\mathrm{N}$ doping [27]. The lower binding energy than a typical $\mathrm{Ti} 2 \mathrm{p}$ signal of $\mathrm{Ti}^{4+}$ oxidation state suggests that titanium cation has a considerable interaction with the doped nitrogen and thus $\mathrm{TiO}_{2}$ lattice is modified [27, 35]. Nitrogen doping accompanies the formation of oxygen vacancies and/or $\mathrm{Ti}^{3+}$ defects, resulting in slight shifts of the Ti $2 p$ peak toward the lower binding energy [36-38]. Hence, the red shifts of the Ti 2p peak in comparison with P25 are used to highlight the successful nitrogen doping into the $\mathrm{TiO}_{2}$ lattice. The XRD results did not indicate the formation of TiN bonds. Therefore, results indicate that the titanium atom bonds with oxygen but not nitrogen. Thus, a shift toward lower binding energy of Ti $2 p$ and the binding energy of $\mathrm{N}$ $1 s$ upon nitrogen addition indicate that the nitrogen can be indeed incorporated into the interstitial positions of $\mathrm{TiO}_{2}$ lattice and the formation of Ti-O-N bonding by partially interstitial with a carbon atom.

The incorporation of nitrogen into the oxide lattice should influence the BE of O 1s as well. The XPS spectra of the $\mathrm{O} 1 \mathrm{~s}$ core level consists of the one peak (Figures 3(e) and 3(f)), at around $529.3-529.5 \mathrm{eV}$, which is ascribed to $\mathrm{Ti}-\mathrm{O}$ bond in the $\mathrm{TiO}_{2}$ lattice [30]. The $\mathrm{O} 1 \mathrm{~s}$ core level moved toward lower energy state from $529.6 \mathrm{eV}$ in $\mathrm{P} 25$ to $529.4 \mathrm{eV}$ in N$\mathrm{TiO}_{2}$ prepared with $\mathrm{A} / \mathrm{T}$ ratio 3.0 and calcined at $400^{\circ} \mathrm{C}$. The peak shifts by $\sim 0.2 \mathrm{eV}$ which might be related to the creation of oxygen vacancies as a result of the nitrogen doping. The shifting of bind energy in both $\mathrm{N}$ 1s and $\mathrm{O}$ 1s region indicates that nitrogen was incorporated into the lattice. The shifts of $\operatorname{Ti} 2 \mathrm{p}_{3 / 2}$ and $\mathrm{O} 1 \mathrm{~s}$ peaks are due to the introduction of oxygen vacancies into the $\mathrm{TiO}_{2}$ lattice [32]. The presence of nitrogen dopant facilitates the formation of oxygen vacancies. The aforementioned results clearly indicate that nitrogen doping is accompanied by oxygen vacancy formation. The optical transitions between the dopant and dopant-induced level and Ti3d orbital explain the observed visible light absorptions of $\mathrm{N}-\mathrm{TiO}_{2}$ nanomaterials. The observed two absorbance edge features in the UV-vis spectra are directly related to the above modification of the electronic states from the dopants.

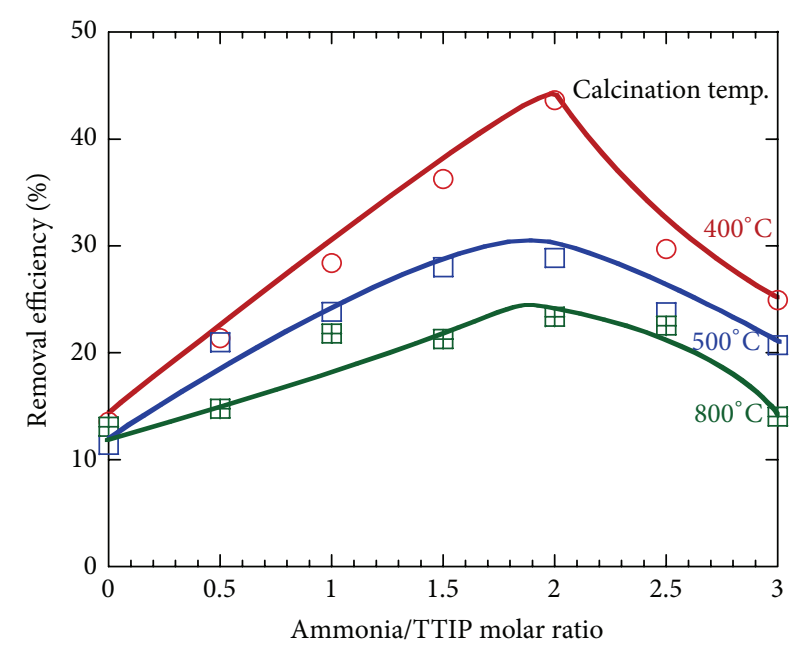

FIGURE 8: The removal efficiency of ethylene photooxidation over $\mathrm{N}-\mathrm{TiO}_{2}$ as function of the various ammonia/TTIP molar ratios. Experimental conditions: $\left[\mathrm{C}_{2} \mathrm{H}_{4}\right]=200 \mathrm{ppmv},\left[\mathrm{H}_{2} \mathrm{O}\right]=25060 \mathrm{ppmv}$, $\left[\mathrm{O}_{2}\right]=21 \%$, light intensity $=16 \mathrm{~mW} / \mathrm{cm}^{2}$, temp. $=30^{\circ} \mathrm{C}$, reaction time $=3 \mathrm{~h}$.

3.6. Visible Light Photocatalytic Activity. To explore the photocatalytic activity of different $\mathrm{N}$-doped $\mathrm{TiO}_{2}$ at different calcination temperatures and $\mathrm{A} / \mathrm{T}$ ratios, the degradation of ethylene under visible light with a cut-off wavelength of $400 \mathrm{~nm}$ was investigated. Carbon dioxide started being formed immediately after the visible light was turned on and ethylene was almost totally converted to $\mathrm{CO}_{2}$ in all measurements. It is obviously that the $\mathrm{N}-\mathrm{TiO}_{2}$ shows significant progress in the photodegradation of ethylene compared to P25 in visible light system. P25 has no obvious photocatalytic activity (less than 1\%) under visible light irradiation. Results suggest modification of $\mathrm{TiO}_{2}$ provides visible-light-sensitive photocatalyst, which can be applied to the photooxidation of ethylene gas, as the band gap of $\mathrm{TiO}_{2}$ was modified by nitrogen doping, evidenced by XPS and UV-visible DRS results. Figure 8 shows the activity of $\mathrm{N}-\mathrm{TiO}_{2}$ catalysts in the presence of visible light for photodegradation of ethylene. The reaction rate increases with the increase in the $\mathrm{A} / \mathrm{T}$ ratio from 0.5 to 2.0, and then decreases in $\mathrm{A} / \mathrm{T}$ ratio from 2.0 to 3.0. The enhancement of photocatalytic activity can be ascribed to an obvious improvement in anatase crystallinity and larger surface area. For the sample prepared with $\mathrm{A} / \mathrm{T}$ ratio 2.0 and 3.0, however, the removal efficiency decreased rapidly, which can be due to its less surface area. The photocatalytic ability of $\mathrm{N}-\mathrm{TiO}_{2}$ samples calcinated at 400 , 500 , and $800^{\circ} \mathrm{C}$ is also examined. It was found that the photocatalytic activity decreased with increasing calcination temperature. The enhancement of photocatalytic activity can be ascribed to an obvious improvement in anatase crystallinity at $400^{\circ} \mathrm{C}$ calcination temperature. Good anatase crystallization is beneficial for reducing the recombination rate of the photogenerated electrons and holes due to the decrease in the number of the defects [39]. Zhao and Yang showed that for photocatalytic oxidation application, anatase is superior to rutile: (a) the conduction band location for anatase is more favorable for driving conjugate reactions 


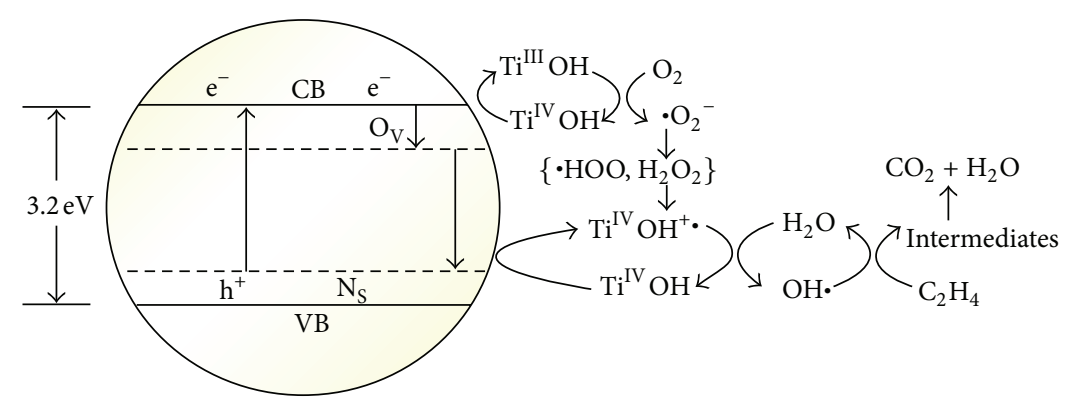

FIGURE 9: Schematic diagram for the process in the photooxidation of ethylene and electron transfer process over $\mathrm{N}_{-} \mathrm{TiO}{ }_{2}$ under visible light illumination.

involving electrons, and (b) very stable surface peroxide groups can be formed at the anatase during photo-oxidation reaction but not on the rutile surface [40]. For the sample calcined at $800^{\circ} \mathrm{C}$, the removal efficiency decreased rapidly, which can be due to its fewer amounts of anatase and small $S_{\mathrm{BET}}$. The result indicates that higher specific surface area, smaller crystallite size, and good anatase crystallization will promote the photocatalytic activity in visible light. The results indicate the $\mathrm{N}-\mathrm{TiO}_{2}$ catalyst prepared with $\mathrm{A} / \mathrm{T}$ ratio 2.0 and calcinated at $400^{\circ} \mathrm{C}$ shows the best photocatalytic ability.

3.7. The Formation Mechanism of $\mathrm{N}$-Doped $\mathrm{TiO}_{2}$. For the pure $\mathrm{TiO}_{2}$, the energy of the visible light is not sufficient to excite electrons from the valence band (VB), as the intrinsic band gap of pure $\mathrm{TiO}_{2}$. Based on the results of UVvis DRS, XRD, and XPS, the nitrogen atoms were weaved into the crystal structure of $\mathrm{TiO}_{2}$ with structure as Ti-O$\mathrm{N}$. $\mathrm{N}-\mathrm{TiO}_{2}$ was active in the visible light irradiation for the degradation of ethylene. The following explanation for the photocatalytic activity of $\mathrm{N}-\mathrm{TiO}_{2}$ in the visible light spectra can be considered. The nitrogen existing at interstitial positions of $\mathrm{TiO}_{2}$ lattice induces localized occupied states and forms midband gap, leading to the red shift of absorption edge and photocatalytic activity under visible light irradiation [41]. The electron $\left(\mathrm{e}^{-}\right)$can be excited from the $\mathrm{N}$-impurity level to the conduction band (CB). The exited electrons are trapped by $\mathrm{O}_{2}$ adsorbed on the catalyst surface, producing $\mathrm{O}_{2}^{-\bullet}$ superoxide anion radicals. After a series of reactions (1)-(12), ethylene molecules are finally mineralized into $\mathrm{CO}_{2}$. DFT calcinations and experimental results indicate that $\mathrm{N}$ doping favored the formation of $\mathrm{O}$ vacancy (subband level $\mathrm{O}_{v}$ ), which was below the bottom of the conduction band [42-47]. Therefore, the electrons $\left(\mathrm{e}^{-}\right)$are excited from the $\mathrm{N}$-impurity level bond to the subband level $\left(\mathrm{O}_{v}\right)$ and then recombine with the hole $\left(\mathrm{h}^{+}\right)$as proved in Figure 9. The holes and electrons react with $\mathrm{OH}^{-}$and $\mathrm{O}_{2}$ molecules on the catalyst surface to form ${ }^{\bullet} \mathrm{OH}$ radicals and $\mathrm{O}_{2}{ }^{-\bullet}$ superoxide anion radicals, respectively. The protonation yields the $\mathrm{HOO}^{\bullet}$ radicals, which after trapping electrons combine to produce $\mathrm{H}_{2} \mathrm{O}_{2}$. The $\mathrm{O}_{2}{ }^{-\bullet}$ radicals then interact with $\mathrm{H}_{2} \mathrm{O}$ adsorbed to produce more ${ }^{\circ} \mathrm{OH}$ radicals. These ${ }^{\circ} \mathrm{OH}$ radicals then react with gaseous ethylene and mineralize it;

$$
\begin{aligned}
& \mathrm{TiO}_{2} \stackrel{\mathrm{h} v}{\longrightarrow} \mathrm{h}^{+}+\mathrm{e}^{-} \\
& \mathrm{S}-\mathrm{H}_{2} \mathrm{O}+\mathrm{h}^{+} \longrightarrow \mathrm{S}-\mathrm{OH}^{\bullet}+\mathrm{H}^{+} \\
& \mathrm{S}-\mathrm{OH}^{-}+\mathrm{h}^{+} \longleftrightarrow \mathrm{S}^{-} \mathrm{OH}^{\bullet} \\
& \mathrm{S}^{\prime}-\mathrm{O}_{2}+\mathrm{e}^{-} \longrightarrow \mathrm{S}^{\prime}-\mathrm{O}_{2}^{-\bullet} \\
& \mathrm{S}-\mathrm{OH}+\mathrm{S}^{\prime}-\mathrm{O}_{2}{ }^{-\bullet} \longrightarrow \mathrm{S}-\mathrm{HO}_{2}{ }^{\bullet}+\mathrm{S}^{\prime}-\mathrm{O}^{-\bullet} \\
& \mathrm{S}^{\prime}-\mathrm{O}_{2} \longrightarrow 2 \mathrm{~S}^{\prime}-\mathrm{O} \\
& \mathrm{S}^{\prime}-\mathrm{O}+\mathrm{e}^{-} \longrightarrow \mathrm{S}^{\prime}-\mathrm{O}^{-\bullet} \\
& \mathrm{S}-\mathrm{H}_{2} \mathrm{O}+\mathrm{S}^{\prime}-\mathrm{O}^{-\bullet} \longrightarrow \mathrm{S}-\mathrm{OH}^{\bullet}+\mathrm{S}-\mathrm{OH}^{-} \\
& \mathrm{S}-\mathrm{HO}_{2}{ }^{\bullet}+\mathrm{S}_{-} \mathrm{HO}_{2}{ }^{\bullet} \longrightarrow \mathrm{S}-\mathrm{H}_{2} \mathrm{O}_{2}+\mathrm{O}_{2} \\
& \mathrm{~S}-\mathrm{H}_{2} \mathrm{O}_{2} \longrightarrow 2 \mathrm{~S}-\mathrm{OH}^{\bullet} \\
& \mathrm{S}-\mathrm{C}_{2} \mathrm{H}_{4}+\mathrm{S}-\mathrm{OH}^{\bullet} \longleftrightarrow \mathrm{S}-\mathrm{C}_{2} \mathrm{H}_{4} \mathrm{OH} \\
& \mathrm{S}-\mathrm{C}_{2} \mathrm{H}_{4} \mathrm{OH}+\mathrm{S}^{\prime}-\mathrm{O}_{2} \longrightarrow \text { intermediates } \longrightarrow \mathrm{CO}_{2}+\mathrm{H}_{2} \mathrm{O}
\end{aligned}
$$

\section{Conclusions}

The observed changes in the UV-vis DRS, XRD, and XPS spectra are providing consistent structural information for $\mathrm{Ti}-\mathrm{O}-\mathrm{N}$ formation; that is, the nitrogen can be incorporated into the interstitial positions of $\mathrm{TiO}_{2}$ lattice, which leads to the enhanced photocatalytic activity in $\mathrm{N}_{-} \mathrm{TiO}_{2}$ samples. It is concluded that the photocatalytic oxidation reactivity of $\mathrm{N}-\mathrm{TiO}_{2}$ under visible light illumination is mainly due to the presence of localized occupied states caused by interstitial nitrogen and the electron/hole pairs generated under visible light irradiation. It has been found that $\mathrm{N}$ dopant retarded the anatase to rutile phase transformation by forming $\mathrm{Ti}-\mathrm{O}-$ $\mathrm{N}$ incorporated into the interstitial position of $\mathrm{TiO}_{2}$ lattice. Moreover, the transformation temperatures of anatase-torutile progressively slightly increase when $\mathrm{N}$ dopant content is increased. The photocatalyst, $\mathrm{N}-\mathrm{TiO}_{2}$ prepared with $\mathrm{A} / \mathrm{T}$ ratio 2.0 and calcinated at $400^{\circ} \mathrm{C}$, shows the highest photocatalytic activity in the oxidation of ethylene. This $\mathrm{N}-\mathrm{TiO}_{2}$ provides an effective visible-light-responsive photocatalyst for future industrial applications in pollution control. 


\section{Acknowledgment}

This research was financially supported by the National Science Council of Taiwan ROC under Grant nos. NSC-1002221-E-005-007 and NSC-100-2120-M-005-002.

\section{References}

[1] T. Horikawa, M. Katoh, and T. Tomida, "Preparation and characterization of nitrogen-doped mesoporous titania with high specific surface area," Microporous and Mesoporous Materials, vol. 110, no. 2-3, pp. 397-404, 2008.

[2] K. Yang, Y. Dai, and B. Huang, "Study of the nitrogen concentration influence on $\mathrm{N}$-doped $\mathrm{TiO}_{2}$ anatase from first-principles calculations," Journal of Physical Chemistry C, vol. 111, no. 32, pp. 12086-12090, 2007.

[3] K. Pomoni, A. Vomvas, and C. Trapalis, "Dark conductivity and transient photoconductivity of nanocrystalline undoped and Ndoped $\mathrm{TiO}_{2}$ sol-gel thin films," Thin Solid Films, vol. 516, no. 6, pp. 1271-1278, 2008.

[4] S. Sato, "Photocatalytic activity of $\mathrm{NO}_{x}$-doped $\mathrm{TiO}_{2}$ in the visible light region," Chemical Physics Letters, vol. 123, no. 1-2, pp. 126-128, 1986.

[5] R. Asahi, T. Morikawa, T. Ohwaki, K. Aoki, and Y. Taga, "Visible-light photocatalysis in nitrogen-doped titanium oxides," Science, vol. 293, no. 5528, pp. 269-271, 2001.

[6] J. Ananpattarachai, P. Kajitvichyanukul, and S. Seraphin, "Visible light absorption ability and photocatalytic oxidation activity of various interstitial $\mathrm{N}$-doped $\mathrm{TiO}_{2}$ prepared from different nitrogen dopants," Journal of Hazardous Materials, vol. 168, no. 1, pp. 253-261, 2009.

[7] Y. T. Lin, C. H. Weng, and T. W. Tzeng, "Photocatalysis and catalytic properties of nano-sized $\mathrm{N}-\mathrm{TiO}_{2}$ catalyst synthesized by Sol-gel methods," Journal of Advanced Oxidation Technologies, vol. 13, no. 3, pp. 297-304, 2010.

[8] B. Kosowska, S. Mozia, A. W. Morawski, B. Grzmil, M. Janus, and K. Kałucki, "The preparation of $\mathrm{TiO}_{2}$-nitrogen doped by calcination of $\mathrm{TiO}_{2} \cdot x \mathrm{H}_{2} \mathrm{O}$ under ammonia atmosphere for visible light photocatalysis," Solar Energy Materials and Solar Cells, vol. 88, no. 3, pp. 269-280, 2005.

[9] F. Peng, L. Cai, L. Huang, H. Yu, and H. Wang, "Preparation of nitrogen-doped titanium dioxide with visible-light photocatalytic activity using a facile hydrothermal method," Journal of Physics and Chemistry of Solids, vol. 69, no. 7, pp. 1657-1664, 2008.

[10] H. Yu, X. Zheng, Z. Yin, F. Tag, B. Fang, and K. Hou, "Preparation of nitrogen-doped $\mathrm{TiO}_{2}$ nanoparticle catalyst and its catalytic activity under visible light," Chinese Journal of Chemical Engineering, vol. 15, no. 6, pp. 802-807, 2007.

[11] Z. Wang, W. Cai, X. Hong, X. Zhao, F. Xu, and C. Cai, "Photocatalytic degradation of phenol in aqueous nitrogendoped $\mathrm{TiO}_{2}$ suspensions with various light sources," Applied Catalysis B, vol. 57, no. 3, pp. 223-231, 2005.

[12] A. Trenczek-Zajac, K. Kowalski, K. Zakrzewska, and M. Radecka, "Nitrogen-doped titanium dioxide-characterization of structural and optical properties," Materials Research Bulletin, vol. 44, no. 7, pp. 1547-1552, 2009.

[13] J. S. Jang, H. G. Kim, S. M. Ji et al., "Formation of crystalline $\mathrm{TiO}_{2-x} \mathrm{~N}_{x}$ and its photocatalytic activity," Journal of Solid State Chemistry, vol. 179, no. 4, pp. 1067-1075, 2006.

[14] H. L. Qin, G. B. Gu, and S. Liu, "Preparation of nitrogen-doped titania using sol-gel technique and its photocatalytic activity,"
Materials Chemistry and Physics, vol. 112, no. 2, pp. 346-352, 2008.

[15] J. Xu, Y. Ao, D. Fu, and C. Yuan J, "Low-temperature preparation of anatase titania-coated magnetite," Journal of Physics and Chemistry of Solids, vol. 69, pp. 1980-1984, 2008.

[16] D. Wu, M. Long, W. Cai, C. Chen, and Y. Wu, "Low temperature hydrothermal synthesis of $\mathrm{N}$-doped $\mathrm{TiO}_{2}$ photocatalyst with high visible-light activity," Journal of Alloys and Compounds, vol. 502, no. 2, pp. 289-294, 2010.

[17] K. M. Parida and B. Naik, "Synthesis of mesoporous $\mathrm{TiO}_{2-x} \mathrm{~N}_{x}$ spheres by template free homogeneous co-precipitation method and their photo-catalytic activity under visible light illumination," Journal of Colloid and Interface Science, vol. 333, no. 1, pp. 269-276, 2009.

[18] N. R. Neti, R. Misra, P. K. Bera, R. Dhodapkar, S. Bakardjieva, and $\mathrm{Z}$. Bastl, "Synthesis of c-doped $\mathrm{TiO}_{2}$ nanoparticles by novel sol-gel polycondensation of resorcinol with formaldehyde for visible-light photocatalysis," Synthesis and Reactivity in Inorganic, Metal-Organic and Nano-Metal Chemistry, vol. 40, no. 5, pp. 328-332, 2010.

[19] K. Bubacz, J. Choina, D. Dolat, E. Borowiak-Paleń, D. Moszyński, and A. W. Morawski, "Studies on nitrogen modified $\mathrm{TiO}_{2}$ photocatalyst prepared in different conditions," Materials Research Bulletin, vol. 45, no. 9, pp. 1085-1091, 2010.

[20] Z. Zhang, X. Wang, J. Long, Q. Gu, Z. Ding, and X. Fu, "Nitrogen-doped titanium dioxide visible light photocatalyst: spectroscopic identification of photoactive centers," Journal of Catalysis, vol. 276, pp. 201-214, 2010.

[21] X. Z. Bu, G. K. Zhang, Y. Y. Gao, and Y. Q. Yang, "Preparation and photocatalytic properties of visible light responsive $\mathrm{N}$-doped $\mathrm{TiO}_{2} /$ rectorite composites," Microporous and Mesoporous Materials, vol. 136, no. 1-3, pp. 132-137, 2010.

[22] C. Liu, X. Tang, C. Mo, and Z. Qiang, "Characterization and activity of visible-light-driven $\mathrm{TiO}_{2}$ photocatalyst codoped with nitrogen and cerium," Journal of Solid State Chemistry, vol. 181, no. 4, pp. 913-919, 2008.

[23] R. Kun, S. Tarján, A. Oszkó et al., "Preparation and characterization of mesoporous $\mathrm{N}$-doped and sulfuric acid treated anatase $\mathrm{TiO}_{2}$ catalysts and their photocatalytic activity under UV and Vis illumination," Journal of Solid State Chemistry, vol. 182, pp. 3076-3084, 2009.

[24] Z. Pap, L. Baia, K. Mogyorósi, A. Dombi, A. Oszkó, and V. Danciu, "Correlating the visible light photoactivity of N-doped $\mathrm{TiO}_{2}$ with brookite particle size and bridged-nitro surface species," Catalysis Communications, vol. 17, pp. 1-7, 2012.

[25] X. Z. Bu, G. K. Zhang, and C. H. Zhang, "Effect of nitrogen doping on anatase-rutile phase transformation of $\mathrm{TiO}_{2}$," Applied Surface Science, vol. 258, pp. 7997-8001, 2012.

[26] Y. P. Peng, E. Yassitepe, Y. T. Yeh, I. Ruzybayev, S. I. Shah, and C. P. Huang, "Photoelectrochemical degradation of azo dye over pulsed laser deposited nitrogen-doped $\mathrm{TiO}_{2}$ thin film," Applied Catalysis B, vol. 125, pp. 465-472, 2012.

[27] H. Jie, H. B. Lee, K. H. Chae et al., "Nitrogen-doped $\mathrm{TiO}_{2}$ nanopowders prepared by chemical vapor synthesis: band structure and photocatalytic activity under visible light," Research on Chemical Intermediates, vol. 38, no. 6, pp. 1171-1180, 2012.

[28] S. U. M. Khan, M. Al-Shahry, and W. B. Ingler, "Efficient photochemical water splitting by a chemically modified n$\mathrm{TiO}_{2}$," Science, vol. 297, no. 5590, pp. 2243-2245, 2002. 
[29] X. X. Wang, S. Meng, X. L. Zhang, H. T. Wang, W. Zhong, and Q. G. Du, "Multi-type carbon doping of $\mathrm{TiO}_{2}$ photocatalyst," Chemical Physics Letters, vol. 444, pp. 292-296, 2007.

[30] N. R. Khalid, E. Ahmed, Z. L. Hong, Y. W. Zhang, and M. Ahmad, "Nitrogen doped $\mathrm{TiO}_{2}$ nanoparticles decorated on graphene sheets for photocatalysis applications," Current Applied Physics, vol. 12, no. 6, pp. 1485-1492, 2012.

[31] Q. J. Xiang, J. G. Yu, and M. Jaroniec, "Nitrogen and sulfur co-doped $\mathrm{TiO}_{2}$ nanosheets with exposed 001 facets: synthesis, characterization and visible-light photocatalytic activity," Physical Chemistry Chemical Physics, vol. 13, no. 11, pp. 4853-4861, 2011.

[32] J. Wang, D. N. Tafen, J. P. Lewis et al., "Origin of photocatalytic activity of nitrogen-doped $\mathrm{TiO}_{2}$ nanobelts," Journal of the American Chemical Society, vol. 131, pp. 12290-12297, 2009.

[33] Q. Xiang, J. Yu, W. Wang, and M. Jaroniec, "Nitrogen self-doped nanosized $\mathrm{TiO}_{2}$ sheets with exposed 001 facets for enhanced visible-light photocatalytic activity," Chemical Communications, vol. 47, no. 24, pp. 6906-6908, 2011.

[34] Y. C. Tang, X. H. Huang, H. Q. Yu, and L. H. Tang, "Nitrogendoped $\mathrm{TiO}_{2}$ photocatalyst prepared by mechanochemical method: doping mechanisms and visible photoactivity of pollutant degradation," International Journal of Photoenergy, vol. 2012, Article ID 960726, 10 pages, 2012.

[35] D. E. Gu, Y. Lu, B. C. Yang, and Y. D. Hu, "Facile preparation of micro-mesoporous carbon-doped $\mathrm{TiO}_{2}$ photocatalysts with anatase crystalline walls under template-free condition," Chemical Communications, no. 21, pp. 2453-2455, 2008.

[36] W. Ren, Z. Ai, F. Jia, L. Zhang, X. Fan, and Z. Zou, "Low temperature preparation and visible light photocatalytic activity of mesoporous carbon-doped crystalline $\mathrm{TiO}_{2}$," Applied Catalysis B, vol. 69, no. 3-4, pp. 138-144, 2007.

[37] E. M. Rockafellow, X. Fang, B. G. Trewyn, K. Schmidt-Rohr, and W. S. Jenks, "Solid-state ${ }^{13} \mathrm{C}$ NMR characterization of carbonmodified $\mathrm{TiO}_{2}$," Chemistry of Materials, vol. 21, no. 7, pp. 11871197, 2009.

[38] Y. Zhang, P. Xiao, X. Zhou, D. Liu, B. B. Garcia, and G. Cao, "Carbon monoxide annealed $\mathrm{TiO}_{2}$ nanotube array electrodes for efficient biosensor applications," Journal of Materials Chemistry, vol. 19, no. 7, pp. 948-953, 2009.

[39] J. Yu, L. Zhang, B. Cheng, and Y. Su, "Hydrothermal preparation and photocatalytic activity of hierarchically sponge-like macro/mesoporous Titania," Journal of Physical Chemistry C, vol. 111, no. 28, pp. 10582-10589, 2007.

[40] J. Zhao and X. Yang, "Photocatalytic oxidation for indoor air purification: a literature review," Building and Environment, vol. 38, no. 5, pp. 645-654, 2003.

[41] C. Di Valentin, G. Pacchioni, and A. Selloni, "Origin of the different photoactivity of $\mathrm{N}$-doped anatase and rutile $\mathrm{TiO}_{2}$," Physical Review B, vol. 70, no. 8, Article ID 085116, 4 pages, 2004.

[42] S. Livraghi, M. C. Paganini, E. Giamello, A. Selloni, C. Di Valentin, and G. Pacchioni, "Origin of photoactivity of nitrogen-doped titanium dioxide under visible light," Journal of the American Chemical Society, vol. 128, no. 49, pp. 15666-15671, 2006.

[43] X. Chen and C. Burda, "The electronic origin of the visible-light absorption properties of C-, $\mathrm{N}$ - and $\mathrm{S}$-doped $\mathrm{TiO}_{2}$ nanomaterials," Journal of the American Chemical Society, vol. 130, no. 15, pp. 5018-5019, 2008.

[44] C. Di Valentin, G. Pacchioni, and A. Selloni, "Theory of carbon doping of titanium dioxide," Chemistry of Materials, vol. 17, no. 26, pp. 6656-6665, 2005.
[45] H. Wang and J. P. Lewis, "Effects of dopant states on photoactivity in carbon-doped $\mathrm{TiO}_{2}$," Journal of Physics Condensed Matter, vol. 17, no. 21, pp. L209-L213, 2005.

[46] H. Li, D. Wang, H. Fan, P. Wang, T. Jiang, and T. Xie, "Synthesis of highly efficient C-doped $\mathrm{TiO}_{2}$ photocatalyst and its photogenerated charge-transfer properties," Journal of Colloid and Interface Science, vol. 354, no. 1, pp. 175-180, 2011.

[47] Z. Wu, F. Dong, W. Zhao, and S. Guo, "Visible light induced electron transfer process over nitrogen doped $\mathrm{TiO}_{2}$ nanocrystals prepared by oxidation of titanium nitride," Journal of Hazardous Materials, vol. 157, no. 1, pp. 57-63, 2008. 

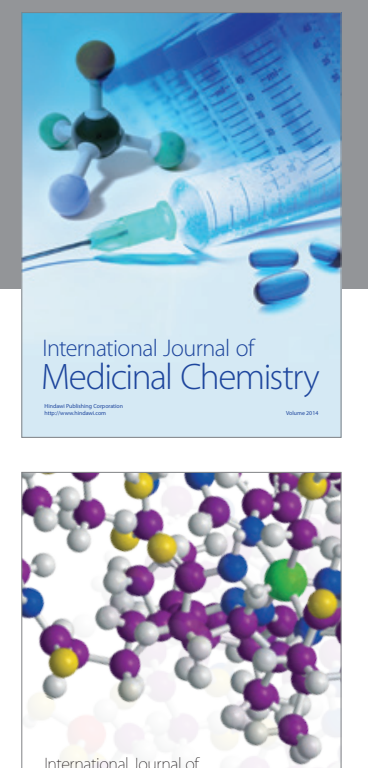

\section{Carbohydrate} Chemistry

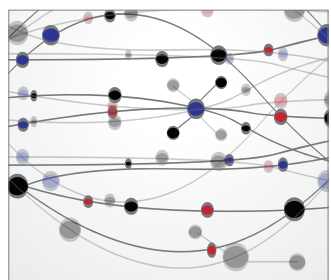

The Scientific World Journal
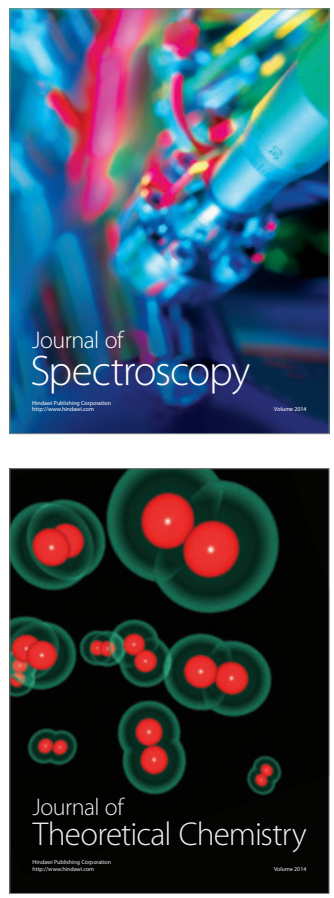
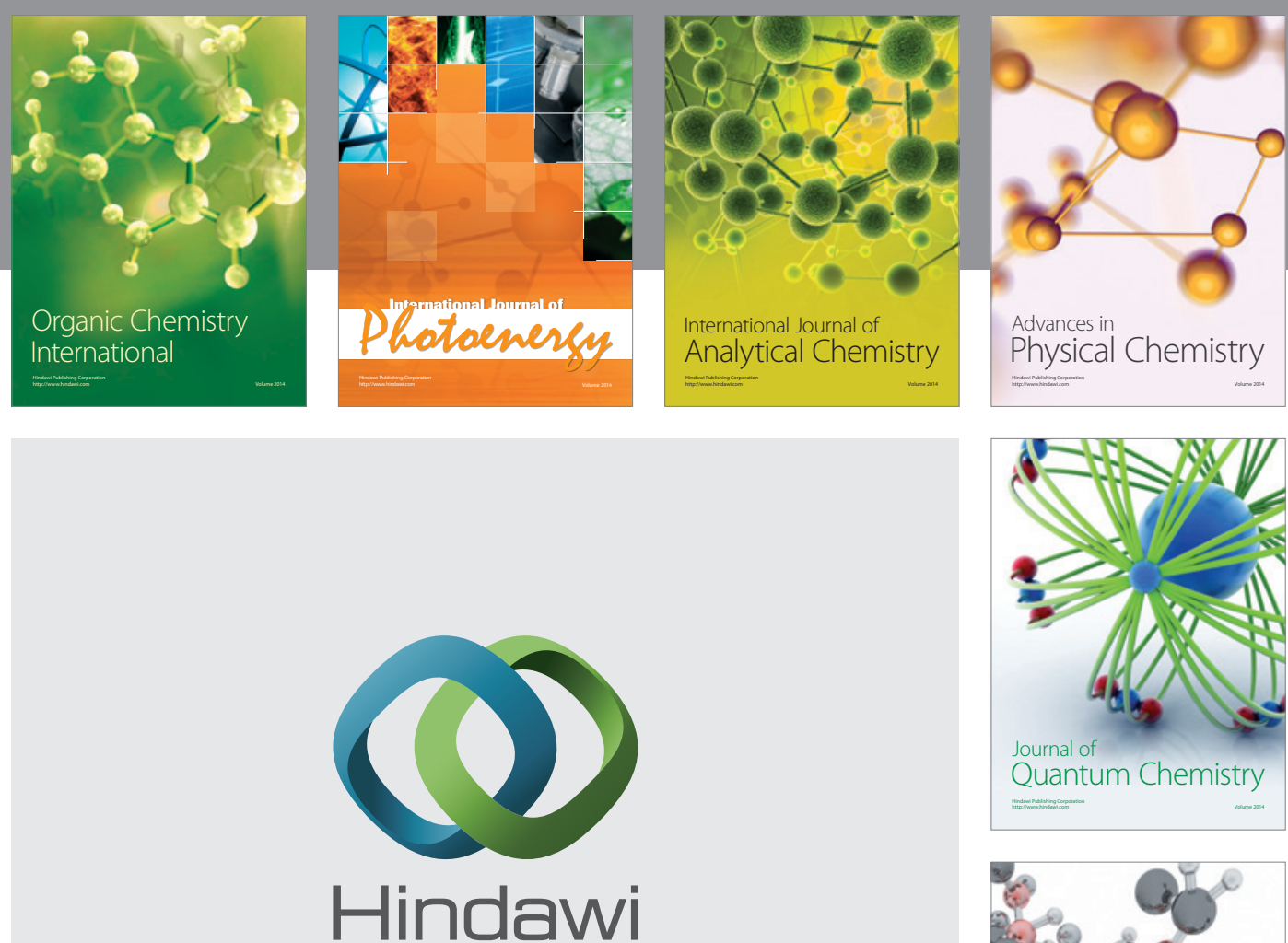

Submit your manuscripts at

http://www.hindawi.com

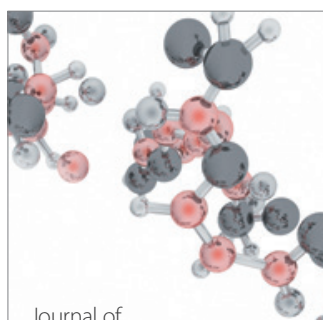

Analytical Methods

in Chemistry

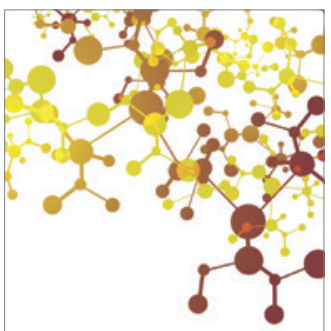

Journal of

Applied Chemistry

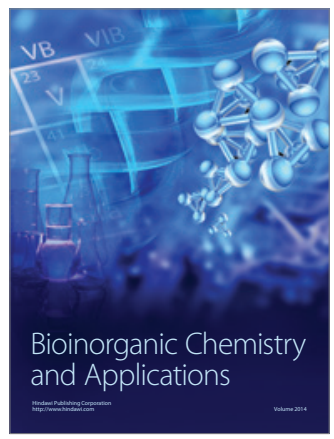

Inorganic Chemistry
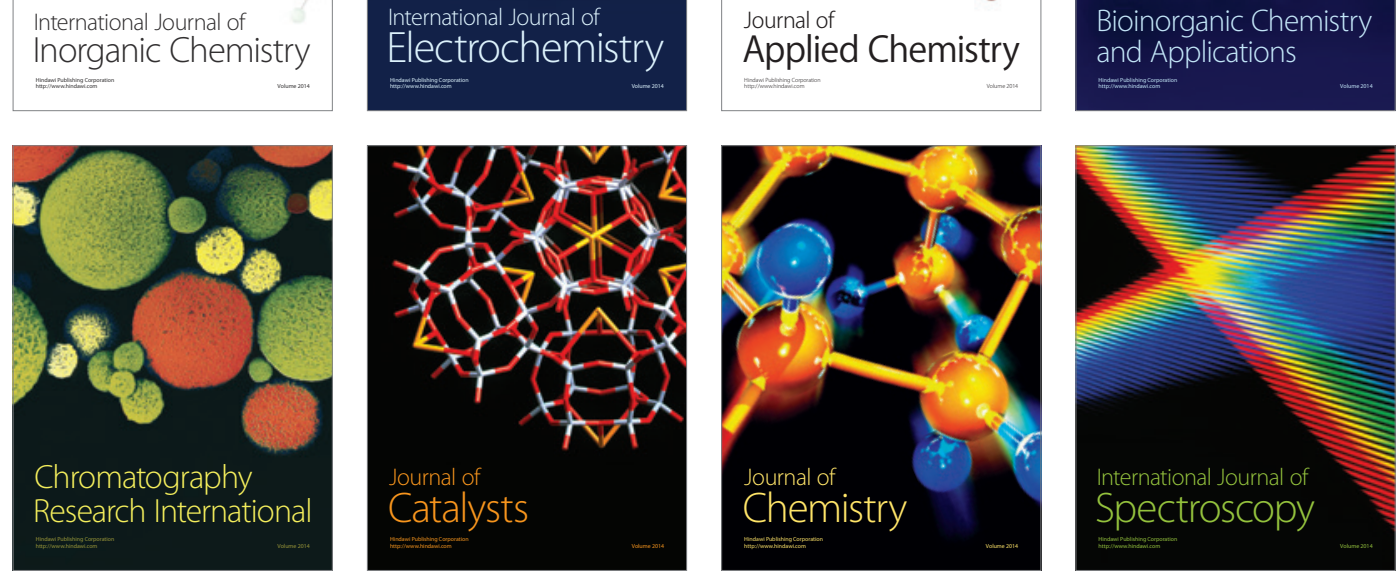